Prepared in cooperation with the lowa Department of Transportation and the lowa Highway Research Board (Project HR-140)

\title{
Flood of June 4-5, 2002, in the Maquoketa River Basin, East-Central lowa
}

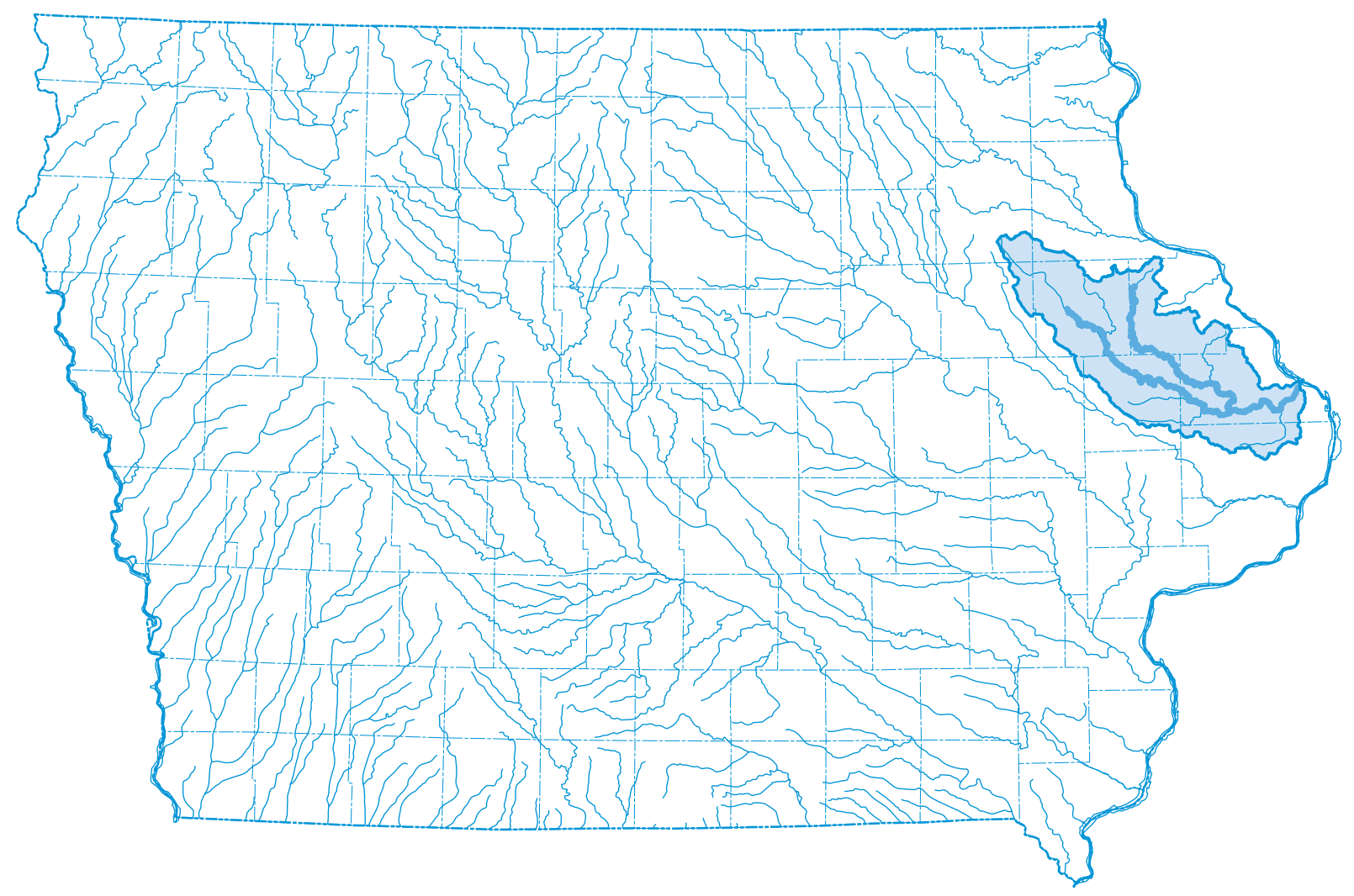

Open-File Report 2004-1250 



\section{Flood of June 4-5, 2002, in the Maquoketa River Basin, East-Central lowa}

By David A. Eash

Prepared in cooperation with the lowa Department of Transportation and the lowa Highway Research Board (Project HR-140)

Open-File Report 2004-1250

U.S. Department of the Interior

U.S. Geological Survey 


\title{
U.S. Department of the Interior Gale A. Norton, Secretary
}

\author{
U.S. Geological Survey \\ Charles G. Groat, Director
}

\author{
U.S. Geological Survey, Reston, Virginia \\ First edition: 2004 \\ Second edition, revised: February 2005 \\ Third edition, revised: August 2006
}

For sale by U.S. Geological Survey, Information Services

Box 25286, Denver Federal Center

Denver, C0 80225

For more information about the USGS and its products:

Telephone: 1-888-ASK-USGS

World Wide Web: http://www.usgs.gov/

Any use of trade, product, or firm names in this publication is for descriptive purposes only and does not imply endorsement by the U.S. Government.

Although this report is in the public domain, permission must be secured from the individual copyright owners to reproduce any copyrighted materials contained within this report.

This third, 2006 edition supersedes the second, 2005 edition.

Suggested citation:

Eash, D.A., 2005, Flood of June 4-5, 2002, in the Maquoketa River Basin, east-central lowa: U.S. Geological Survey Open-File Report 2004-1250, 29 p. 


\section{Contents}

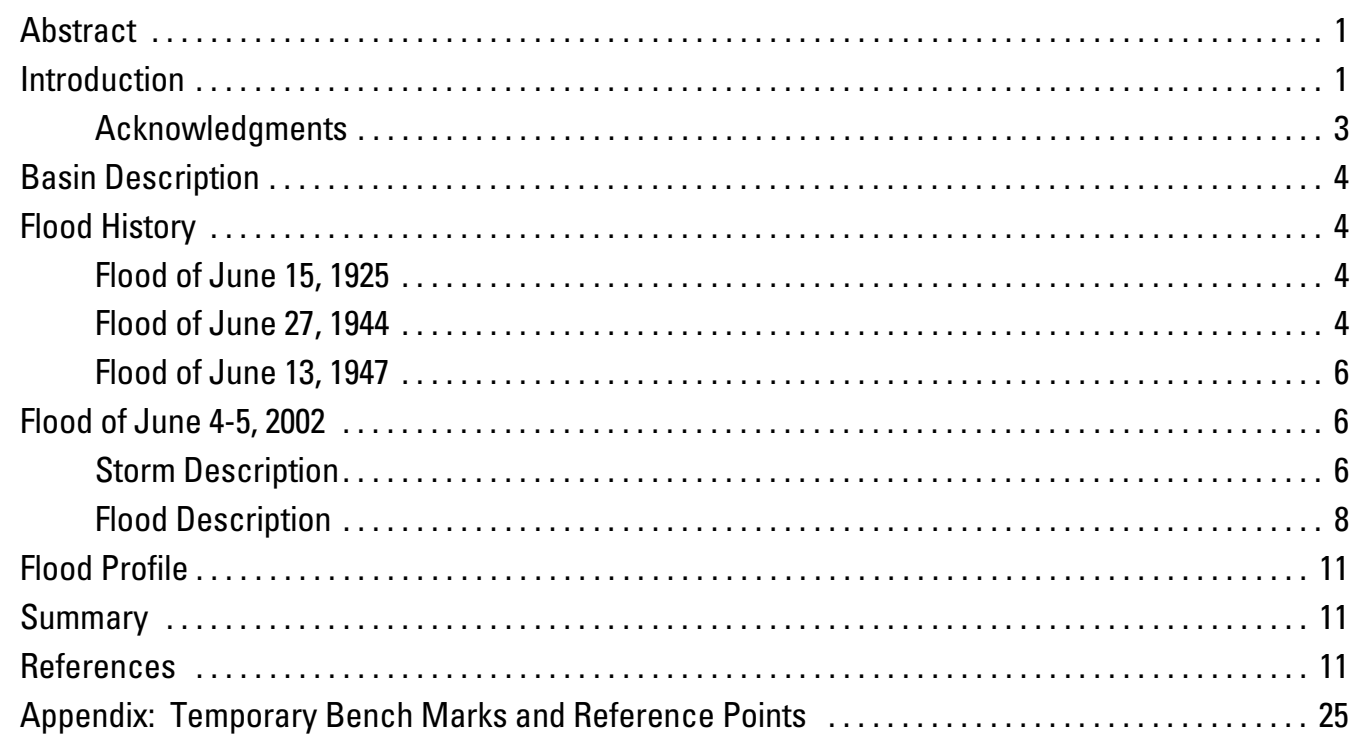

\section{Figures}

1. Map showing Maquoketa River Basin and lines of equal rainfall for 48 hours

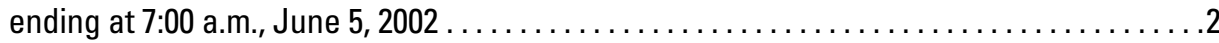

2. Graph showing hourly rainfall for June $3-4,2002$, at rain gages in the

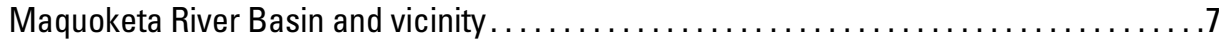

3. Discharge hydrographs at continuous-record, streamflow-gaging

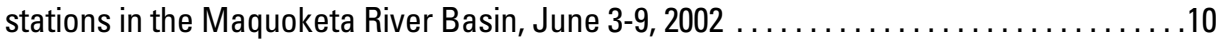

4-8. Graphs showing profile of the June 2002 flood for the Maquoketa River, lowa:

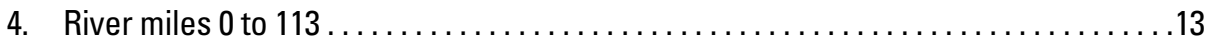

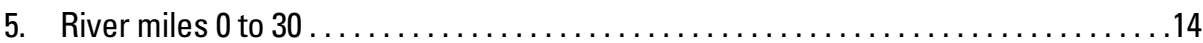

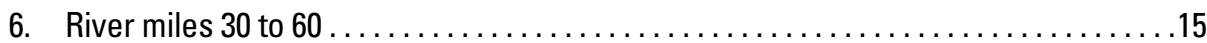

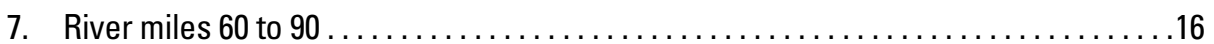

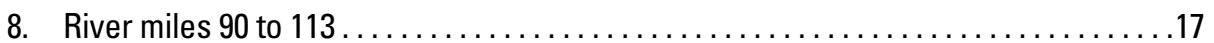

9-12. Graphs showing profile of the June 2002 flood for the North Fork Maquoketa River, lowa:

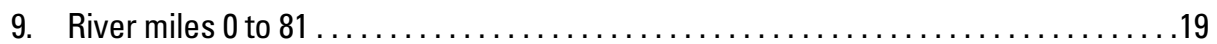

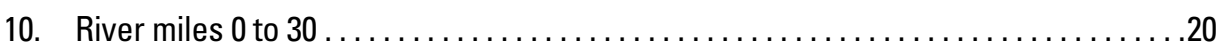

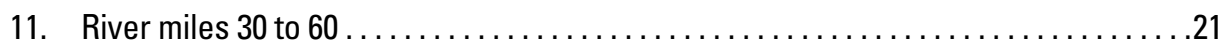

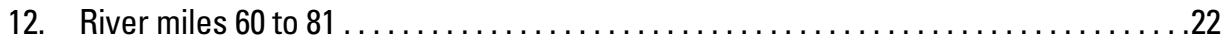




\section{Tables}

1. National Flood Insurance Program Bureau and Statistical Agent lowa loss report for selected counties, June 4-5, 2002, as of December 31, $2003 \ldots \ldots \ldots \ldots \ldots . .3$

2. Maximum stages and discharges for 2002 and selected largest-flood years, and the corresponding recurrence intervals, at streamflow-gaging stations and an ungaged site in the Maquoketa River Basin, lowa .................... 5

3. Twenty-four-hour rainfall amounts at selected rain gages in northeast and

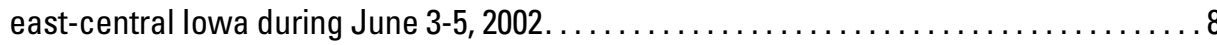

4. Magnitude and frequency of theoretical rainfall amounts for selected storm periods in the vicinity of Worthington, Dubuque County, lowa $\ldots \ldots \ldots \ldots \ldots \ldots \ldots . . .8$

5. Elevations of high-water marks used in the June 2002 flood profile for the Maquoketa River, lowa......................................... 18

6. Elevations of high-water marks used in the June 2002 flood profile for the North Fork Maquoketa River, lowa

\section{Conversion Factors and Datum}

\begin{tabular}{lll}
\hline Multiply & By & To obtain \\
\hline & & \\
inch (in.) & 2.54 & centimeter $(\mathrm{cm})$ \\
foot (ft) & 0.3048 & meter $(\mathrm{m})$ \\
mile (mi) & 1.609 & kilometer $(\mathrm{km})$ \\
square mile $\left(\mathrm{mi}^{2}\right)$ & 2.590 & square kilometer $\left(\mathrm{km}^{2}\right)$ \\
cubic foot per second $\left(\mathrm{ft}^{3} / \mathrm{s}\right)$ & 0.02832 & cubic meter per second $\left(\mathrm{m}^{3} / \mathrm{s}\right)$ \\
\hline
\end{tabular}

Elevation or vertical coordinate information is referenced to the National Geodetic Vertical Datum of 1929 (NGVD 29). Elevation refers to distance above or below NGVD 29. NGVD 29 can be converted to the North American Vertical Datum of 1988 (NAVD 88) by using the National Geodetic Survey conversion utility available at URL http://www.ngs.noaa.gov/TOOLS/Vertcon/vertcon.html.

Water year is the 12-month period from 0ctober 1 through September 30 . The water year is designated by the calendar year in which it ends and which includes 9 of the 12 months. Thus, the year ending September 30, 2003, is called the "2003 water year." 


\title{
Flood of June 4-5, 2002, in the Maquoketa River Basin, East-Central lowa
}

\author{
By David A. Eash
}

\section{Abstract}

Severe flooding occurred on June 4-5, 2002, in the Maquoketa River Basin in Delaware, Dubuque, Jackson, and Jones Counties, following thunderstorm activity over eastcentral Iowa. The rain gage at Cascade, Iowa, recorded a 14-hour rainfall of 6.0 inches at noon on June 4. Radar indications estimated as much as 8 to 10 inches of rain fell in the upper-middle part of the Maquoketa River Basin. Peak discharges on the Maquoketa River at Monticello of 47,500 cubic feet per second (recurrence interval estimated to be greater than 500 years as computed using flood-estimation equations developed by the U.S. Geological Survey), and at the Maquoketa River near Maquoketa streamflow-gaging station of 47,900 cubic feet per second (recurrence interval about 50 years), were determined for the flood. The peak discharge of the 2002 flood is nearly equal that of the 1944 flood (48,000 cubic feet per second), the largest flood on record in the Maquoketa River Basin. The 2002 flood is the largest known flood in the North Fork Maquoketa River Basin. A peak discharge of 22,600 cubic feet per second (recurrence interval about 110 years) was determined for the flood at the North Fork Maquoketa River near Fulton gaging station. Information about the basin and flood history, the 2002 thunderstorms and associated flooding, and a profile of high-water marks are presented for selected reaches along the Maquoketa and North Fork Maquoketa Rivers.

\section{Introduction}

Thunderstorms caused severe flooding in east-central Iowa in June 2002 in the area roughly bounded by Cedar Rapids, Dubuque, and Davenport, Iowa (fig. 1). New maximum peak discharge records were set at five U.S. Geological Survey (USGS) streamflow-gaging stations in the Maquoketa and Little Maquoketa River Basins and in the Duck Creek Basin in Scott County (fig. 1). Flooding occurred in several cities and towns where many homes and businesses were damaged and where hundreds of people were forced to evacuate their homes.
Many highways and roads were closed and several bridges were damaged as a result of the flooding. The Iowa Department of Natural Resources (IDNR) reported that sewage treatment facilities in about 10 cities and a mobile home park were forced to bypass their wastewater-treatment plants and to discharge directly into rivers and streams to avoid sewage backup into homes (Pitt, Waterloo-Cedar Falls Courier, June 5, 2002; Gersema, Associated Press, Cedar Rapids Gazette, June 6, 2002). Flood profiles and peak discharges for the June 2002 flood in the Indian Creek Basin in Linn County, Iowa, are presented in the report Flood of June 4, 2002, in the Indian Creek Basin, Linn County, Iowa (Eash, 2004).

A State disaster emergency was declared within days of the flood for eight counties that included Clayton, Clinton, Delaware, Dubuque, Jackson, Jones, Linn, and Scott. A Federal disaster proclamation followed including 17 counties; in addition to the above counties, the counties of Allamakee, Benton, Buchanan, Cedar, Fayette, Iowa, Johnson, Muscatine, and Winneshiek were included. The flooding damaged an estimated 1,004 homes in eight counties; including 22 homes with major damage and eight homes destroyed (U.S. Department of Commerce, National Oceanic and Atmospheric Administration, and National Weather Service, National Climate Data Center, at uniform resource locator (URL) http://www4.ncdc.noaa.gov/ cgi-win/wwcgi.dll?wwEvent $\sim$ storms). Public property damage in eastern Iowa due to flooding was at least $\$ 7.2$ million, for which the greatest damage occurred in Linn County $(\$ 3.2$ million), Dubuque County ( $\$ 2.1$ million), and Jones County (\$1.3 million). Table 1 shows private property damage claims reported for residential and non-residential buildings in eight selected counties in eastern Iowa (Bonnie Shepard, Federal Emergency Management Agency (FEMA), National Flood Insurance Program Bureau and Statistical Agent, written commun., March 2004).

This report provides information about the June 2002 thunderstorms and ensuing flood in the Maquoketa River Basin. Flood elevations at selected sites along the Maquoketa and North Fork Maquoketa Rivers in Delaware, Dubuque, Jackson, and Jones Counties are presented as flood profiles. 


\section{Flood of June 4-5, 2002, in the Maquoketa River Basin, East-Central, lowa}
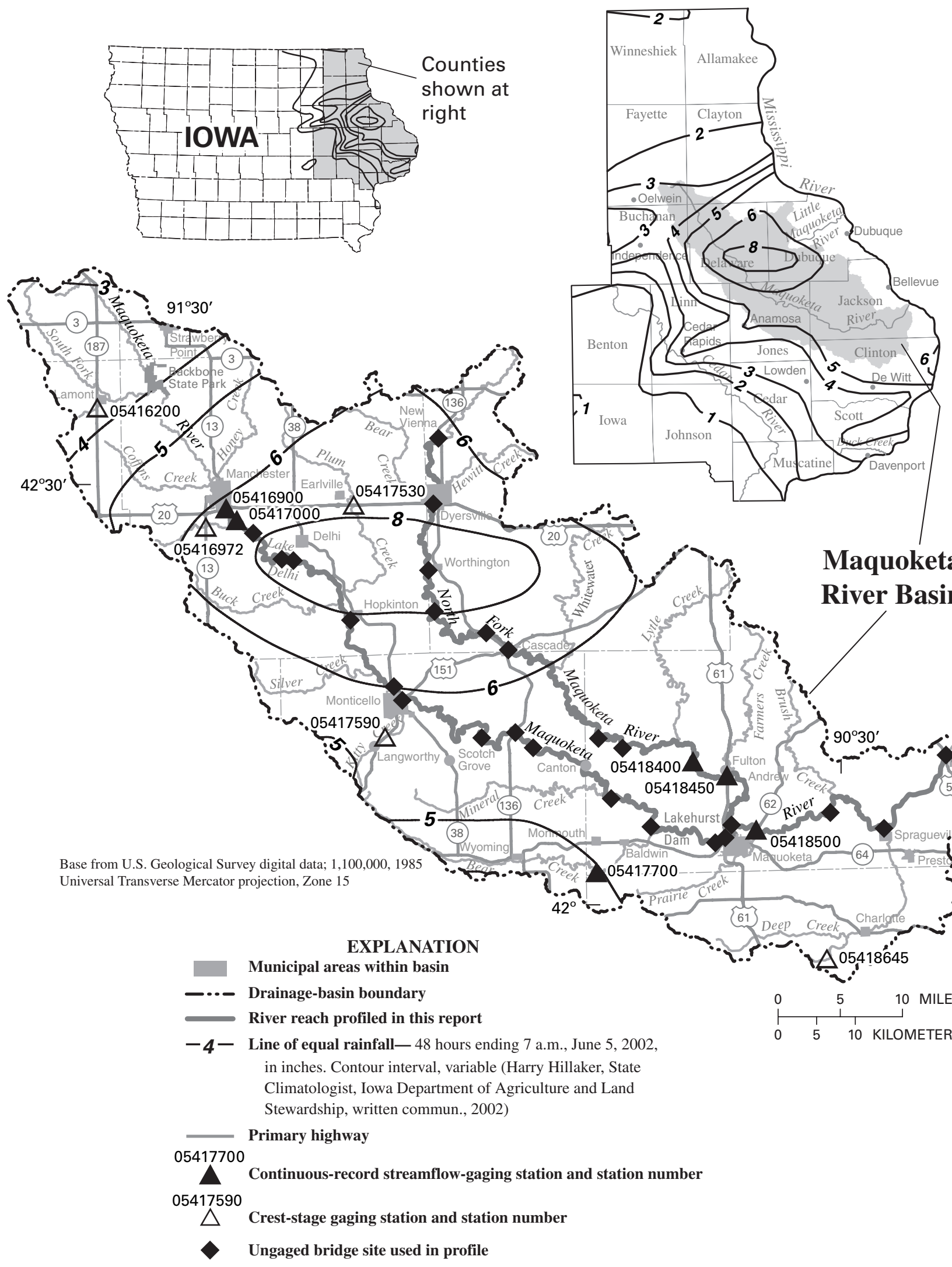

Figure 1. Maquoketa River Basin and lines of equal rainfall for 48 hours ending at 7:00 a.m., June 5, 2002. 
Table 1. National Flood Insurance Program Bureau and Statistical Agent lowa loss report for selected counties, June 4-5, 2002, as of December 31, 2003.

[Source: Bonnie Shepard, Federal Emergency Management Agency, National Flood Insurance Program Bureau and Statistical Agent, written commun., March 2004. ND, no data]

\begin{tabular}{|c|c|c|c|c|}
\hline County & Occupancy & $\begin{array}{l}\text { Buildings with } \\
\text { damage }\end{array}$ & $\begin{array}{l}\text { Building damage } \\
\text { (dollars) }\end{array}$ & $\begin{array}{c}\text { Contents damage } \\
\text { (dollars) }\end{array}$ \\
\hline Clayton & Single-family residential & ND & ND & ND \\
\hline Clayton & Multiple occupancy & ND & ND & ND \\
\hline Clayton & Non-residential & ND & ND & ND \\
\hline Clinton & Single-family residential & 5 & 34,652 & 0 \\
\hline Clinton & Multiple occupancy ${ }^{1}$ & 1 & 5,377 & 0 \\
\hline Clinton & Non-residential & 1 & 2,480 & 0 \\
\hline Delaware & Single-family residential & 28 & 278,639 & 17,062 \\
\hline Delaware & Multiple occupancy & ND & ND & ND \\
\hline Delaware & Non-residential & ND & ND & ND \\
\hline Dubuque & Single-family residential & 11 & 55,444 & 20,154 \\
\hline Dubuque & Multiple occupancy & ND & ND & ND \\
\hline Dubuque & Non-residential & ND & ND & ND \\
\hline Jackson & Single-family residential & ND & ND & ND \\
\hline Jackson & Multiple occupancy & ND & ND & ND \\
\hline Jackson & Non-residential & 1 & 2,644 & 0 \\
\hline Jones & Single-family residential & 6 & 21,693 & 2,159 \\
\hline Jones & Multiple occupancy & ND & ND & ND \\
\hline Jones & Non-residential & 2 & 49,328 & 69,776 \\
\hline Linn & Single-family residential & 11 & 77,033 & 4,241 \\
\hline Linn & Multiple occupancy & ND & ND & ND \\
\hline Linn & Non-residential & 2 & 28,057 & 0 \\
\hline Scott & Single-family residential & 26 & 224,635 & 27,737 \\
\hline Scott & Multiple occupancy $^{2}$ & 5 & 70,521 & 0 \\
\hline Scott & Non-residential & 3 & 18,874 & 4,289 \\
\hline
\end{tabular}

${ }^{1}$ Two to four family residential.

${ }^{2}$ Other residential.

This report was prepared in cooperation with the Iowa Department of Transportation (IDOT) and the Iowa Highway Research Board. A list of other Iowa flood-profile reports published by the USGS can be obtained from the World Wide Web at URL http://ia.water.usgs.gov/projects/profiles/.

\section{Acknowledgments}

The author expresses his gratitude to the following: David Allen, Water Resources Section, IDNR, for providing an additional high-water mark for the June 4-5, 2002, flood along the Maquoketa River; Bruce Chrystal and Jim Whitman, IDOT, for providing elevation data for temporary bench marks at bridges; Harry Hillaker, State Climatologist, Iowa Department of Agriculture and Land Stewardship, for providing an isohyetal map of rainfall for the 48-hour period ending at 7:00 a.m. on June 5, 2002; and Bonnie Shepard, National Flood Insurance Program Bureau and Statistical Agent, FEMA, for providing private property damage claims for eight counties in Iowa. The author also expresses gratitude to the following USGS employees: Gina Renzi, Jason Smith, Greg Littin, and Aimee Donnelly for collecting field data for the determination of water-surface and bench-mark elevations listed in this report, and Ed Fischer for computing the indirect measurement and the determination of bench-mark elevations. 


\section{Flood of June 4-5, 2002, in the Maquoketa River Basin, East-Central, lowa}

\section{Basin Description}

The Maquoketa River Basin is located in east-central and northeast Iowa (fig. 1). The basin is oriented in a general northwest to southeast direction and drains $1,879 \mathrm{mi}^{2}$ (Larimer, 1957). The Maquoketa River originates in Fayette County and flows about $150 \mathrm{mi}$ through the cities of Manchester, Monticello, and Maquoketa to the mouth at the Mississippi River in eastern Jackson County. The North Fork Maquoketa River, a major tributary to the Maquoketa River with a drainage area of $592 \mathrm{mi}^{2}$ (Larimer, 1957), originates in Dubuque County and flows 97 mi through the cities of New Vienna, Dyersville, and Cascade to its mouth in Jackson County.

Approximately 60 percent of the Maquoketa River Basin, comprising the southeast or lower part of the basin, lies within the Southern Iowa Drift Plain landform region (Prior, 1991) (landform regions not shown in fig. 1). The majority of the remainder of the basin, comprising the northwest or upper part of the basin, lies in the Iowan Surface landform region. A small part of the basin, comprising about $6 \mathrm{mi}^{2}$ of the headwaters of the North Fork Maquoketa River Basin, lies within the Paleozoic Plateau landform region. The topography in the basin changes across the two predominate landform regions, from the gently rolling terrain of the Iowan Surface in the upper part of the basin to the steeply to gently rolling terrain of the Southern Iowa Drift Plain in the lower part of the basin. In northwest Delaware County, the Maquoketa River valley changes for a few miles from a gently-sloped valley to a rugged gorge in Backbone State Park. Farther downstream in central Delaware County, a few miles southeast of Manchester, the Maquoketa River enters a canyon-like valley that persists throughout much of the remaining length of the river (Iowa Natural Resources Council, 1958). Land use in the basin is predominately agricultural and includes some wooded areas.

Eight low-head dams have been constructed across the Maquoketa River (Iowa Conservation Commission, 1979); no dams have been constructed across the North Fork Maquoketa River. Six of the dams on the Maquoketa River were originally built for hydroelectric power (Iowa Natural Resources Council, 1958); only the Lakehurst dam upstream from the city of Maquoketa in Jackson County (fig. 1) is currently operating as a hydroelectric dam. The Lake Delhi dam is the largest dam on the Maquoketa River at a height of $38 \mathrm{ft}$ (Iowa Conservation Commission, 1979). Lake Delhi (Federally recognized as Hartwick Lake) is approximately $8 \mathrm{mi}$ in length and 450 acres in area. The local name "Lake Delhi" was adopted in recognition of the nearby town of Delhi in Delaware County (fig. 1).

\section{Flood History}

Continuous records of streamflow have been collected in the Maquoketa River Basin since September 1913, at the USGS streamflow-gaging station Maquoketa River near Maquoketa (station number 05418500). Peak stages, discharges, and recurrence intervals for the largest known floods, including the June 2002 flood, are listed in table 2 for gaging stations in the Maquoketa River Basin. The gaging stations listed in table 2 also are listed in the USGS National Water Information System (NWIS) database, and users may obtain surface-water data for Iowa gaging stations, including information on types of data available and years of data collection, at URL http://waterdata. usgs.gov/ia/nwis/sw. Descriptions of historic floods in the Maquoketa River Basin are limited; available information is summarized for floods that occurred in 1925, 1944, and 1947.

\section{Flood of June 15, 1925}

The largest known flood in the upper part of the Maquoketa River Basin (1925-2003) occurred on June 15, 1925, prior to installation of the Maquoketa River near Manchester gaging station (station number 05417000, fig. 1) in 1933. The 1925 flood caused extensive damage in Manchester (Iowa Natural Resources Council, 1958). Professor F.A. Nagler, University of Iowa, computed a peak discharge of $25,400 \mathrm{ft}^{3} / \mathrm{s}$ for the $1925 \mathrm{flood}$; this discharge has a recurrence interval of approximately 130 years (table 2).

\section{Flood of June 27, 1944}

The largest flood on record in the Maquoketa River Basin occurred on June 27, 1944. Saturated soils and intense local thunderstorms that began late on June 25 and ended around noon on June 26 caused severe flooding on the lower reaches of the Maquoketa River. The area of greatest rainfall was in southeastern Jones County where unofficial measurements of 11.0 inches were reported. In the Maquoketa River Basin in eastern Jones County, unofficial rainfall amounts ranged between 7.5 and 9.5 inches. At Monmouth, in southwestern Jackson County, 5.02 inches of rain fell in 13.5 hours and at Cascade, in southwestern Dubuque County, 5.38 inches of rain fell in 4 hours and 40 minutes (U.S. Department of Commerce, Weather Bureau, and Iowa Department of Agriculture, 1944). Floodwaters damaged many highways and railroad grades, washed out many culverts and bridges, and caused widespread erosion damage, siltation, and crop losses. Damages were primarily limited to rural property, crops, and pasture. The June 1944 flood in the Maquoketa River Basin inundated 9,872 acres and total damage was $\$ 342,845$; including damage of $\$ 286,480$ for crops and pasture and $\$ 56,365$ for rural property (damage estimates for urban property were not available) (Iowa Natural Resources Council, 1958). At the Maquoketa River near Maquoketa gaging station (station number 05418500, fig. 1), the peak discharge of $48,000 \mathrm{ft}^{3} / \mathrm{s}$ for the flood of June 27 , 1944 , is the largest known discharge $(1903,1914-2003)$ and has a recurrence interval of approximately 50 years (table 2). 
Table 2. Maximum stages and discharges for 2002 and selected largest-flood years, and the corresponding recurrence intervals, at streamflow-gaging stations and an ungaged site in the Maquoketa River Basin, lowa.

$\left[\mathrm{mi}^{2}\right.$, square miles; $\mathrm{ft}^{3} / \mathrm{s}$, cubic feet per second; <, less than; >, greater than; --, not determined]

\begin{tabular}{|c|c|c|c|c|c|c|}
\hline Site & $\begin{array}{l}\text { Period of peak- } \\
\text { flow record } \\
\text { (water years) }\end{array}$ & $\begin{array}{l}\text { Drainage area } \\
\qquad\left(\mathrm{mi}^{2}\right)\end{array}$ & Date & $\begin{array}{l}\text { Peak stage } \\
\text { (feet) }\end{array}$ & $\begin{array}{l}\text { Peak } \\
\text { discharge } \\
\left(\mathrm{ft}^{3} / \mathrm{s}\right)\end{array}$ & $\begin{array}{l}\text { Recurrence } \\
\text { interval }^{2} \\
\text { (years) }\end{array}$ \\
\hline $\begin{array}{l}\text { Crest-stage gaging station } \\
\text { 05416200 Lamont Creek tributary at } \\
\text { Lamont }\end{array}$ & 1991-2003 & 1.78 & $\begin{array}{l}6 / 01 / 2000 \\
6 / 04 / 2002\end{array}$ & $\begin{array}{l}20.13 \\
15.74\end{array}$ & $\begin{array}{l}{ }^{3} 635 \\
{ }^{3} 138\end{array}$ & $\begin{array}{r}9 \\
<2\end{array}$ \\
\hline $\begin{array}{l}\text { Continuous-record gaging station } \\
05416900 \text { Maquoketa River at } \\
\text { Manchester }\end{array}$ & 2001-2003 & 275 & $6 / 04 / 2002$ & 18.35 & 10,800 & 10 \\
\hline $\begin{array}{l}\text { Crest-stage gaging station } \\
\text { 05416972 Sand Creek near } \\
\text { Manchester }\end{array}$ & $1991-2003$ & 11.0 & $\begin{array}{l}6 / 13 / 2000 \\
6 / 04 / 2002\end{array}$ & $\begin{array}{l}14.33 \\
19.31\end{array}$ & $\begin{array}{r}1,880 \\
{ }^{3} 4,290\end{array}$ & $\begin{array}{r}6 \\
30\end{array}$ \\
\hline $\begin{array}{l}\text { Continuous-record gaging station } \\
05417000 \text { Maquoketa River near } \\
\text { Manchester }\end{array}$ & $\begin{array}{l}1925,1928-30 \\
1933-73,1976-83\end{array}$ & 305 & $\begin{array}{l}6 / 15 / 1925 \\
6 / 13 / 1947 \\
7 / 09 / 1951\end{array}$ & $\begin{array}{l}-- \\
21.40 \\
19.65\end{array}$ & $\begin{array}{r}4_{25,400} \\
20,000 \\
16,800\end{array}$ & $\begin{array}{r}130 \\
60 \\
30\end{array}$ \\
\hline $\begin{array}{l}\text { Miscellaneous measurement at ungaged } \\
\text { bridge site Maquoketa River at State } \\
\text { Highway } 38 \text { at Monticello }\end{array}$ & 2002 & 600 & 6/04/2002 & ${ }^{5} 810.40$ & $6_{47,500}$ & ${ }^{7}>500$ \\
\hline $\begin{array}{l}\text { Crest-stage gaging station } \\
05417590 \text { Kitty Creek near } \\
\text { Langworthy }\end{array}$ & 1966-92 & 14.4 & $\begin{array}{l}7 / 19 / 1969 \\
7 / 08 / 1986\end{array}$ & $\begin{array}{l}90.24 \\
88.68\end{array}$ & $\begin{array}{r}6,700 \\
2,100\end{array}$ & $\begin{array}{r}100 \\
17\end{array}$ \\
\hline $\begin{array}{l}\text { Continuous-record gaging station } \\
05417700 \text { Bear Creek near Monmouth }\end{array}$ & $1944,1958-76$ & 61.3 & $\begin{array}{l}6 /--/ 1944 \\
9 / 21 / 1965 \\
5 / 16 / 1974\end{array}$ & $\begin{array}{r}8 \\
81.50 \\
13.76 \\
11.80\end{array}$ & $\begin{array}{r}-- \\
7,340 \\
3,410\end{array}$ & $\begin{array}{r}-- \\
80 \\
7\end{array}$ \\
\hline $\begin{array}{l}\text { Crest-stage gaging station } \\
\text { 05418645 Williams Creek near } \\
\text { Charlotte }\end{array}$ & $1989-2003$ & 1.77 & $\begin{array}{l}5 / 29 / 1996 \\
6 / 04 / 2002\end{array}$ & $\begin{array}{l}13.02 \\
12.25\end{array}$ & $\begin{array}{l}{ }^{3} 990 \\
3870\end{array}$ & $\begin{array}{r}14 \\
9\end{array}$ \\
\hline
\end{tabular}

\footnotetext{
${ }^{1}$ All values at current datums. 50-year recurrence intervals and to nearest 10 years for 50- to 200-year recurrence intervals.

${ }^{3}$ Estimated.

${ }^{4}$ Discharge computed by Prof. F.A. Nagler, University of Iowa.

${ }^{5}$ Elevation referenced to the National Geodetic Vertical Datum of 1929.

${ }^{6}$ Discharge computed from indirect measurement.

${ }^{7}$ Computed using regional regression equations (Eash, 2001).

${ }^{8}$ Stage affected by backwater.

${ }^{9}$ Prior to Sept. 30, 1972, gaging station at different site and datum.
}

${ }^{2}$ Interpolated using Bulletin 17B flood-frequency analyses (Interagency Advisory Committee on Water Data, 1982) and rounded to nearest 5 years for 20 - to 


\section{Flood of June 4-5, 2002, in the Maquoketa River Basin, East-Central, lowa}

\section{Flood of June 13, 1947}

Severe flooding that affected much of Iowa during June 1947, also involved the Maquoketa River Basin. Frequent rains during April and early June saturated soils in the basin, and excessive rains over northeastern Iowa during the remainder of June caused one of the most widespread flood periods of record in this area. Most of the flooding was caused by intense, widespread thunderstorms during June 12-13, during which more than 4 inches of rain fell in the upper part of the Maquoketa River Basin. Floodwaters caused much damage to roads and bridges, and agricultural land. Flooding along the Maquoketa River caused severe damage in Manchester, where much of the business area was inundated with several feet of water (Iowa Natural Resources Council, 1958). The flood forced the evacuation of at least 50 families in Manchester and damages in the city were estimated at several hundred thousand dollars. Flooding along the North Fork Maquoketa River resulted in some residential damage in Dyersville. The June 1947 flood in the Maquoketa River Basin inundated 10,059 acres and total damage was $\$ 598,680$; including damage of $\$ 269,060$ for crops and pasture, $\$ 48,540$ for rural property, and $\$ 281,080$ for urban property (Iowa Natural Resources Council, 1958). At the Maquoketa River near Manchester gaging station (station number 05417000 ), the peak discharge of $20,000 \mathrm{ft}^{3} / \mathrm{s}$ for the flood of June 13, 1947, is the second largest known discharge (1925-2003) and has a recurrence interval of approximately 60 years (table 2 ).

\section{Flood of June 4-5, 2002}

The flood of June 4-5, 2002, in the Maquoketa River Basin is nearly equal the largest flood on record (June 1944) for the period 1903, and 1914-2003, and is the largest known flood in the North Fork Maquoketa River Basin for the period 1974, 1977-91, and 1999-2003.

\section{Storm Description}

The flood was the result of a series of thunderstorms that deluged northeast and east-central Iowa on June 3-4. Figure 2 shows hourly rainfall amounts for June 3-4, 2002, at four selected rain gages located in northeast and east-central Iowa (fig. 1). Hourly data collected at Cascade (fig. 2A), located less than $10 \mathrm{mi}$ from the area of greatest rainfall shown in figure 1, may provide a general indication of the timing and intensity of the rainfall in the upper-middle part of the Maquoketa River Basin. The greatest intensity of rainfall at Cascade occurred between 11:00 p.m. and midnight on June 3 during which 1.6 inches of rain fell. All of the rainfall at Cascade occurred during a 31-hour period, of which the majority of the rainfall (6.0 inches of the total 6.5 inches) occurred during a 14-hour period ending at noon on June 4. Data from the four rain gages (fig. 2) indicate that the majority of the rainfall occurred during about a 15-hour period from 9:00 p.m. on June 3 to noon on June 4.

Figure 1 shows an isohyetal map of the areal distribution of rainfall for the 48-hour period ending at 7:00 a.m. on June 5, 2002; data were provided by Harry Hillaker, State Climatologist, Iowa Department of Agriculture and Land Stewardship (written commun., June 2002). A 48-hour time period is shown in figure 1 to indicate total rainfall for the storm because the majority of the rainfall occurred during two 24-hour collection periods (7:00 a.m. observation times). Table 3 lists each 24-hour rainfall amount for June 3-5, 2002, for the 13 rain gages nearest to the Maquoketa River Basin (U.S. Department of Commerce, National Oceanic and Atmospheric Administration, and National Climatic Data Center, 2002a; and Iowa Department of Agriculture and Land Stewardship, State Climatologist Office, 2002). Table 3 and figure 2 indicate that minor amounts of rain (between about 0.1 and $0.6 \mathrm{inch}$ ) fell in the Maquoketa River Basin within the 24-hour time period preceding rainfall observations on June 3; although the Dubuque WSO airport rain gage observed 2.92 inches at midnight on June 3, 2.32 inches of this 24-hour rainfall was observed between 9:00 p.m. and midnight. A 72-hour time period and rainfall total is listed in table 3 for June 3-5 to include all rainfall that could be considered contributing to the flood of June 4-5, 2002.

Figure 2 shows that rainfall amounts for selected time periods at Cascade and the Dubuque WSO airport were approximately 3.2 and 3.6 inches, respectively, for a 6-hour period; 5.7 and 5.5 inches, respectively, for a 12-hour period; and 6.2 and 5.9 inches, respectively, for a 24-hour period. At Dyersville, 5 inches of rainfall was reported in a 12-hour period (U.S. Department of Commerce, National Oceanic and Atmospheric Administration, and National Weather Service, National Climate Data Center, at URL http://www4.ncdc.noaa.gov/ cgi-win/wwcgi.dll?wwEvent $\sim$ storms). Radar estimates indicated total rainfall amounts were as high as 8 to 10 inches in Delaware and Dubuque Counties, with more than 10 inches in western Dubuque County (U.S. Department of Commerce, National Oceanic and Atmospheric Administration, and National Weather Service, 2002, WS Form E-5). The Rainfall Frequency Atlas of the Midwest (Huff and Angel, 1992) provides isohyetal maps of the spatial distribution of theoretical rainfall amounts in Iowa for selected rain periods and recurrence intervals. Table 4 lists the magnitude and frequency of theoretical rainfall amounts for selected rain periods (durations) interpolated from isohyetal maps shown in Huff and Angel (1992). The theoretical rainfall amounts listed in table 4 were interpolated for the Worthington area in Dubuque County (located near the Delaware-Dubuque County line, fig. 1) because this area was reported to have received the greatest rainfall amount in June 2002. 

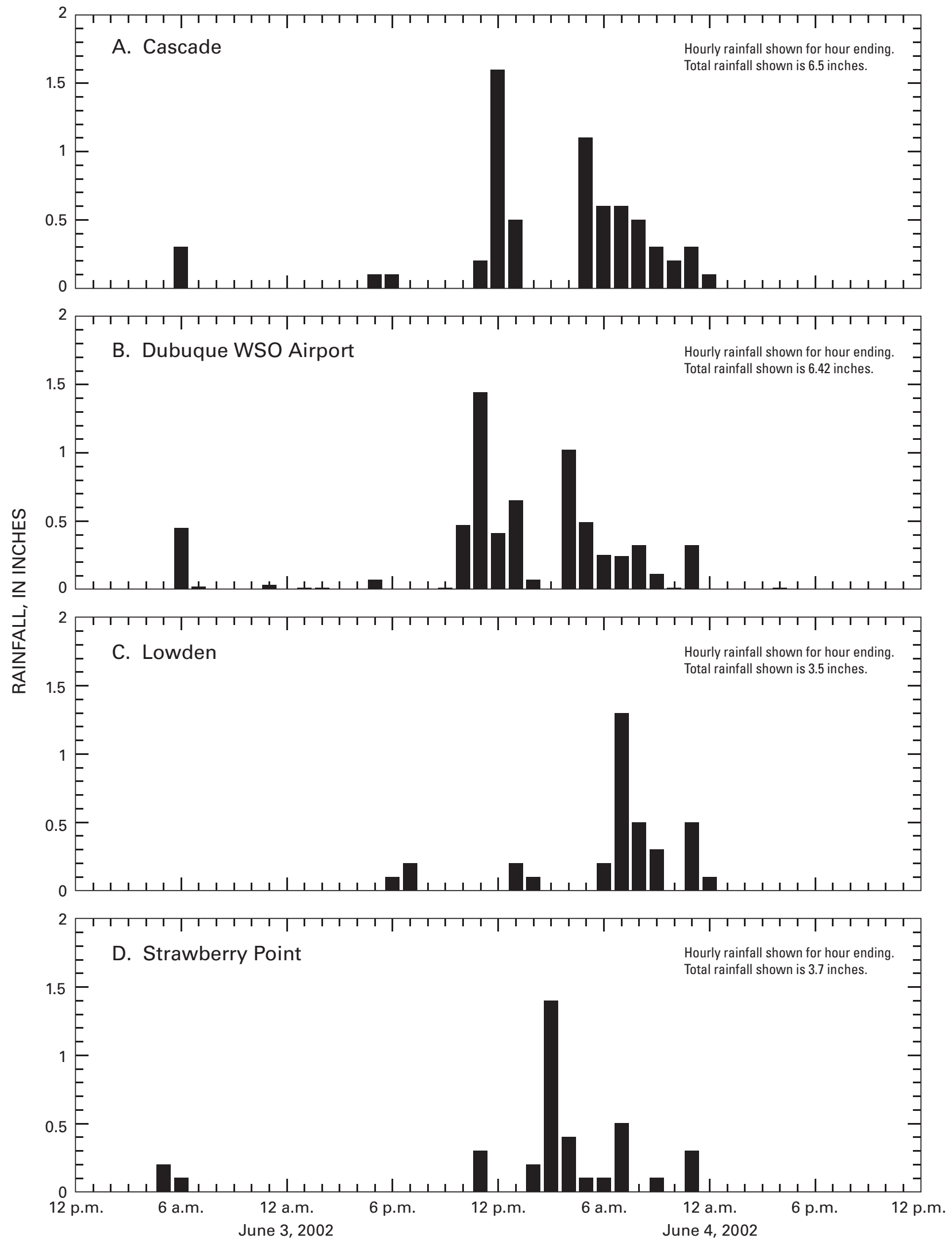

TIME, IN HOURS

Figure 2. Hourly rainfall for June 3-4, 2002, at rain gages in the Maquoketa River Basin and vicinity (U.S. Department of Commerce, National Oceanic and Atmospheric Administration, and National Climatic Data Center, 2002b). 


\section{Flood of June 4-5, 2002, in the Maquoketa River Basin, East-Central, lowa}

Table 3. Twenty-four-hour rainfall amounts at selected rain gages in northeast and east-central lowa during June 3-5, 2002.

[ND, no data]

\begin{tabular}{|c|c|c|c|c|c|}
\hline \multirow{2}{*}{ Rain gage } & \multirow{2}{*}{$\begin{array}{l}\text { Observation } \\
\text { time }\end{array}$} & \multicolumn{3}{|c|}{ 24-hour rainfall, in inches ${ }^{1,2}$} & \multirow{2}{*}{$\begin{array}{l}\text { 72-hour rainfall total, } \\
\text { in inches }\end{array}$} \\
\hline & & June 3, 2002 & June 4, 2002 & June 5, 2002 & \\
\hline Anamosa $1 \mathrm{WNW}$ & 7 a.m. & 0.25 & 2.00 & 1.50 & 3.75 \\
\hline Bellevue Lock \& Dam 12 & 6 a.m. & 0.14 & 3.23 & 1.05 & 4.42 \\
\hline Cascade & 8 a.m. & 0.42 & 5.05 & 1.02 & 6.49 \\
\hline Cedar Rapids No. 1 & 6 p.m. & 0.21 & 4.76 & ND & 4.97 \\
\hline De Witt & 8 a.m. & 0.25 & 3.25 & 1.44 & 4.94 \\
\hline Dubuque Lock \& Dam 11 & 6 a.m. & 0.17 & 4.86 & 0.86 & 5.89 \\
\hline Dubuque WSO Airport & Midnight & 2.92 & 3.50 & ND & 6.42 \\
\hline Independence & 7 a.m. & 0.26 & 2.30 & 0.95 & 3.51 \\
\hline Lowden & Midnight & 0.42 & 3.08 & ND & 3.50 \\
\hline Manchester No. 2 & 7 a.m. & 0.38 & 4.03 & 1.51 & 5.92 \\
\hline Maquoketa $3 \mathrm{~S}$ & 7 a.m. & 0.39 & 4.80 & 0.99 & 6.18 \\
\hline Oelwein $2 \mathrm{~S}$ & 7 a.m. & 0.34 & 2.15 & 0.62 & 3.11 \\
\hline Strawberry Point & 7 a.m. & 0.61 & 3.12 & 0.63 & 4.36 \\
\hline
\end{tabular}

Table 4. Magnitude and frequency of theoretical rainfall amounts for selected storm periods in the vicinity of Worthington, Dubuque County, lowa.

[Rainfall amounts interpolated from isohyetal maps in Rainfall Frequency Atlas of the Midwest, Huff and Angel, 1992]

\begin{tabular}{cccc}
\hline \multirow{2}{*}{$\begin{array}{c}\text { Duration } \\
\text { (hours) }\end{array}$} & \multicolumn{3}{c}{$\begin{array}{c}\text { Rainfall (inches) for indicated } \\
\text { recurrence interval (years) }\end{array}$} \\
\cline { 2 - 4 } & $\mathbf{2 5}$ & $\mathbf{5 0}$ & $\mathbf{1 0 0}$ \\
\hline 6 & 4.1 & 4.7 & 5.1 \\
12 & 4.7 & 5.2 & 6.3 \\
24 & 5.5 & 6.0 & 6.5 \\
48 & 6.0 & 6.8 & 7.7 \\
72 & 6.3 & 7.2 & 8.3 \\
\hline
\end{tabular}

Tables 4 and 2 list recurrence intervals for two different components of a hydrologic event-rainfall and runoff, respectively, and for different locations in the Maquoketa River Basin. Recurrence interval is the average interval of time during which a given rainfall or flood will be equalled or exceeded once. For example, a flood with a magnitude that is expected to be exceeded on average once during any 100-year period (recurrence interval) has a 1-percent chance of being exceeded during any particular year. This flood, commonly termed the 100-year flood, is the theoretical peak discharge against which actual flood-peak discharges are compared. Although the recurrence interval represents the long-term average period between rainfalls or floods of a specific magnitude, rare rainfalls or floods could occur at shorter intervals or even within the same year.

\section{Flood Description}

As a result of the intense rainfall, severe flooding occurred in the Maquoketa River Basin. Peak discharges on the Maquoketa River for the flood of June 4-5, 2002, of 47,500 $\mathrm{ft}^{3} / \mathrm{s}$ at Monticello (State Highway 38, fig. 1), and $47,900 \mathrm{ft}^{3} / \mathrm{s}$ at the Maquoketa River near Maquoketa gaging station (station number 05418500, State Highway 62), were determined for the flood (table 2). The peak discharge of the 2002 flood is nearly equal that of the 1944 flood, the largest flood on record $\left(48,000 \mathrm{ft}^{3} / \mathrm{s}\right)$ in the Maquoketa River Basin. The 2002 flood is the largest known flood in the North Fork Maquoketa River Basin. A peak discharge of $22,600 \mathrm{ft}^{3} / \mathrm{s}$ was determined at the North Fork Maquoketa River near Fulton gaging station (station 
number 05418400 , County Road E17). The recurrence interval for the peak discharge of 47,500 $\mathrm{ft}^{3} / \mathrm{s}$ for the Maquoketa River at Monticello is estimated to be greater than 500 years as computed using flood-estimation equations developed by the USGS (table 2; Eash, 2001).

Figure 3 shows discharge hydrographs for all three active, continuous-record, streamflow-gaging stations in the Maquoketa River Basin for the period June 3-9, 2002. Due to equipment damage from the flood at the North Fork Maquoketa River near Fulton gaging station, only a partial discharge hydrograph is available (fig. 3B). Major flooding in the Maquoketa and North Fork Maquoketa River Basins began on June 4 and peaked at the North Fork Maquoketa River near Fulton and Maquoketa River near Maquoketa gaging stations on June 5 (figs. 3B and 3C). The discharge hydrographs shown in figure 3 indicate the smallest increase in discharge occurred at the Maquoketa River at Manchester gaging station (fig. 3A), which is consistent with rainfall amounts depicted in figure 1. The largest discharge occurred at the Maquoketa River near Maquoketa gaging station (fig. 3C), which measures the combined discharge of the Maquoketa and North Fork Maquoketa Rivers (fig. 1). Figure 3 illustrates the magnitude of the 2002 flood in comparison to selected theoretical, floodfrequency discharges. Recurrence intervals estimated for the 2002 flood at the Manchester (fig. 3A), Fulton (fig. 3B), and Maquoketa (fig. 3C) gaging stations are about 10, 110, and 50 years, respectively (table 2), as computed using Bulletin 17B flood-frequency analyses (Interagency Advisory Committee on Water Data, 1982).

The flood stage established by the National Weather Service for the Maquoketa gaging station is $24.0 \mathrm{ft}$, which is the stage at which water begins affecting agricultural fields in the Maquoketa area and several storm sewers in town (URL http://www.crh.noaa.gov/cgi-bin/ahps.cgi?dvn\&maqi4). The Maquoketa River near Maquoketa was above flood stage from June 4-7, 2002 (fig. 3C), and the peak stage of $34.09 \mathrm{ft}$ (table 2) exceeded the flood stage at this site by almost $10.1 \mathrm{ft}$. Flood stages are not available for the other two gaging stations shown in figure 3.

The following flood description information presented in this section was obtained from newspaper articles in the Cedar Rapids Gazette (Gersema, Associated Press, June 6; Love, June 7, June 8, June 11, June 19, and July 13, 2002; Love and Lucas, June 5, 2002; and Owens, June 5, 2002) and the Waterloo-Cedar Falls Courier (Pitt, June 5, 2002), and from on-line sources obtained from the Cedar Rapids Gazette (June 4, 2002, URL http://www.gazetteonline.com), the City of Maquoketa (City Manager's Column: The Flood of '02, June 6, 2002, URL http://www.maquoketaia.com), and the U.S.

Department of Commerce, National Oceanic and Atmospheric Administration, and National Weather Service (National Climate Data Center, URL http://www4.ncdc.noaa.gov/ cgi-win/wwcgi.dll?wwEvent storms).

In Jones County, the greatest flood damage occurred in Monticello. Sally Hinrichsen, Monticello City Clerk, reported severe water damage to homes in an area of several blocks due to flooding from the Maquoketa River and Kitty Creek. High stages along the Maquoketa River backed up water along Kitty Creek, which caused additional flooding in southeast Monticello. Dana Edwards, Monticello Public Works Director, reported that rising floodwaters from the Maquoketa River and Kitty Creek inundated the Monticello wastewater-treatment plant for the first time since it was built in 1939 and caused the loss of electrical service to the pumps at the plant. As a result of the loss of operation of the wastewater-treatment plant, the city was forced to bypass the plant and to discharge sewage directly into Kitty Creek. Joshua Smith, Monticello City Administrator, reported flood damage to 91 homes and 18 businesses in Monticello and estimated damages to homes, businesses, and city infrastructure at $\$ 4$ million, which included about $\$ 500,000$ of damage to the city wastewater-treatment plant. Terry Reynolds, American Red Cross Disaster Coordinator, reported residents from more than 70 homes in Monticello were at least temporarily displaced as a result of the flooding. All roads into Monticello were closed for a time on June 4. U.S. Highway 151 was closed in Monticello due to the road being washed out near the Maquoketa River bridge and also was closed near Langworthy. State Highway 38 was closed near Monticello and floodwaters from Bear Creek inundated State Highway 64 near Wyoming. Joe Wagner, District Conservationist, Natural Resources Conservation Service, reported that soil erosion in Jones County was severe as a result of the intense rainfall and that tributaries transported large sediment loads downstream. In February 2004, the City of Monticello bought out two private homes in the Maquoketa River flood plain, to create a green space with the property, with the assistance of funding provided by FEMA (Love, Cedar Rapids Gazette, March 1, 2004).

In Dubuque County, the greatest flood damage occurred in Dyersville. Tim Pins, Dyersville Emergency Management Coordinator, reported that about 50 homes along the North Fork Maquoketa River were flooded in Dyersville and another 30 to 40 homes in a six-block area of town were evacuated. The area in Dyersville affected the worst was near the mouths of Bear and Hewitt Creeks. To avoid sewage backups into homes in Dyersville, the city was forced to bypass the wastewatertreatment plant and to discharge directly into the North Fork Maquoketa River. Damage to infrastructure in Dyersville was estimated to be about $\$ 1.5$ million and to homes about $\$ 1$ million. Rick Kremer, Cascade Fire Chief, reported that about six homes were evacuated in Cascade after sandbags along a dike on the southeast side of town failed to hold floodwaters of the North Fork Maquoketa River.

In Jackson County, Buddy Olson, Jackson County Emergency Management Coordinator, reported that three bridges in the county were damaged and many county roads were washed out. Flooding from Prairie Creek closed a section of U.S. Highway 61 and South Main Street south of Maquoketa. During the flood, South Main Street was inundated with 2 to $3 \mathrm{ft}$ of water and a man became stranded in his car on the bridge crossing Prairie Creek. With floodwaters racing across either end of the bridge, a rescue squad tied themselves together with ropes to retrieve the man. Flooding also caused the closure of State Highway 64 near Preston. 

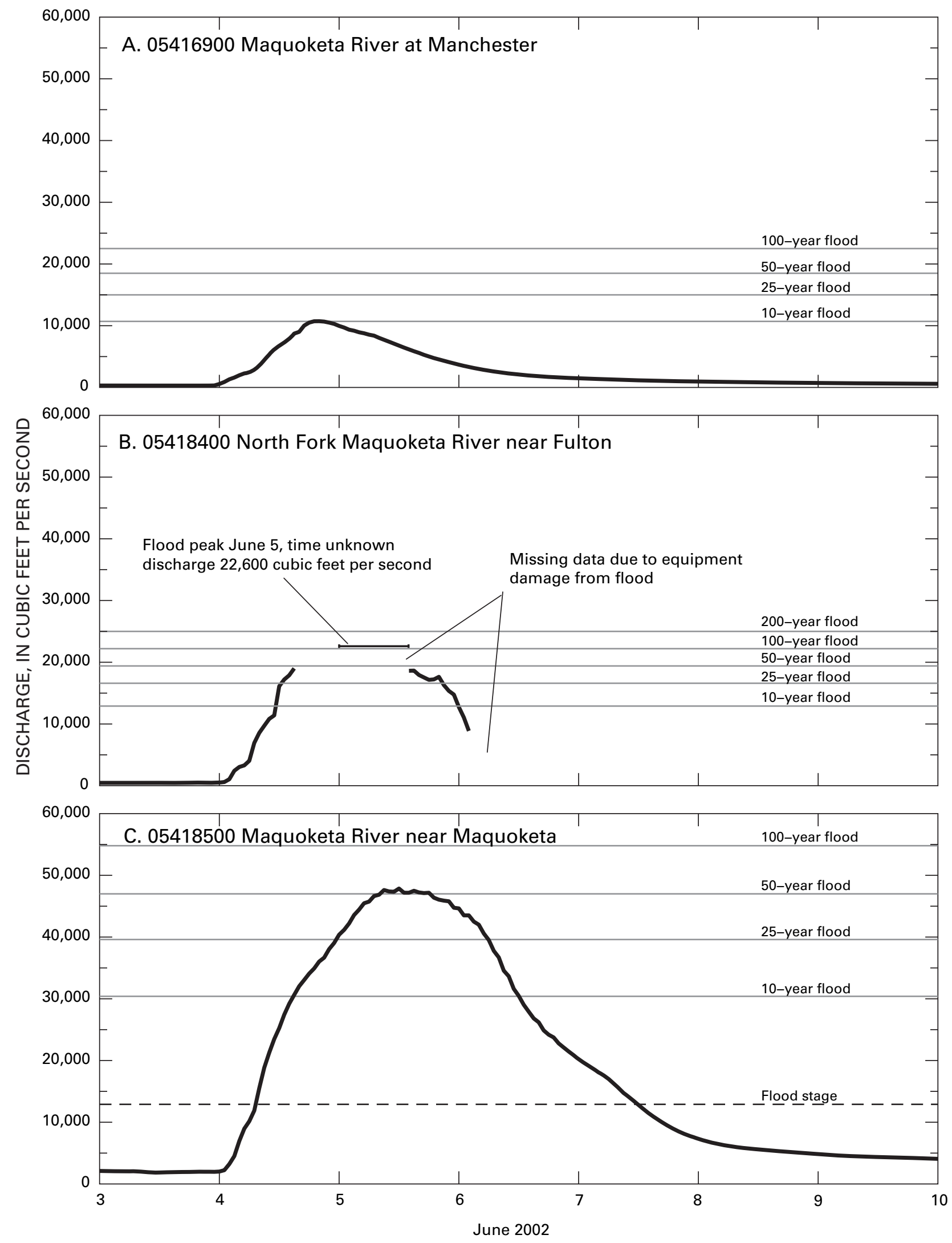

Figure 3. Discharge hydrographs at continuous-record, streamflow-gaging stations in the Maquoketa River Basin, June 3-9, 2002. 
In Delaware County, the intense rainfall caused severe soil erosion and crop damage. Brian Hillers, Soil Conservationist, Natural Resources Conservation Service, reported that runoff from the thunderstorms in recently tilled fields without grass waterways may have eroded as much as 30 tons per acre of topsoil and that drainage off hillsides cut deep gullies into many fields. To avoid sewage backups into homes in Hopkinton, the city was forced to bypass the wastewater-treatment plant and to discharge directly into the Maquoketa River. In Clinton County, State Highway 136 was closed in Charlotte.

As a result of the intense rainfall, the pool level of Lake Delhi (fig. 1) rose rapidly during the night of June 3-4 while the floodgates of the Lake Delhi dam were set for normal flows. Officials fully opened two of the three gates at 7:00 a.m. on June 4. While there were assertions that this action exacerbated the flooding in Monticello $20 \mathrm{mi}$ downstream, officials from the Iowa Department of Natural Resources and the U.S. Army Corps of Engineers did not believe this was the case.

\section{Flood Profile}

To develop a flood profile, the USGS measured the elevation of high-water marks (HWMs) at selected bridge sites along selected reaches of the Maquoketa and North Fork Maquoketa Rivers. River miles were determined for the bridge sites using a geographic information system to measure the distance along each river reach from the mouth using 1:24,000-scale topographic-map data. HWMs were measured at all Federal and State Highway bridges and at USGS streamflow-gaging stations along the selected river reaches. Additional HWMs were measured at county road bridges to keep the maximum distance between points at about 10 river mi. The flood profiles were determined using HWMs generally located immediately downstream and one bridge-length upstream from selected bridges. The HWMs were flagged within 4 days of the flood peak and surveyed to temporary bench marks (see appendix) at bridges within 4 weeks of the flood peak and were later referenced to the National Geodetic Vertical Datum of 1929 by differential leveling or differential positioning using a global positioning system. The line connecting the marks on the profiles (figs. 4-12 following references) is a linear interpolation and, therefore, only approximates the flood elevation between marks; the line does not depict the effects on the profile caused by intermediate bridges or flood-plain and channel features. An additional HWM was provided by David Allen, Water Resources Section, IDNR (written commun., July 2002) for the downstream side of the Lakehurst dam. The HWMs used to profile the June 4-5, 2002, flood in the Maquoketa River Basin are listed in tables 5 and 6 and are plotted by river mile in figures 4-12. Primary highways referred to in the report are shown in figure 1 ; secondary roads are not shown.

The June 2002 flood along the Maquoketa River is profiled from U.S. Highway 52 near Green Island upstream to U.S. Highway 20 near Manchester. The 111-mi river reach that was profiled along the Maquoketa River is shown in figures 1 and 4-8, and the 18 stream sites where HWMs were measured are listed in table 5 and follow the Maquoketa River profile. Lowwater profiles measured on December 3-4, 2002, also are shown for each river reach. The low-water profiles were obtained for the purpose of indicating the range in stage along the stream and to define the low-water slope.

The June 2002 flood on the North Fork Maquoketa River is profiled from Rockdale Road near Maquoketa upstream to State Highway 136 in New Vienna. The 80-mi river reach that was profiled along the North Fork Maquoketa River is shown in figures 1 and 9-12, and the 11 stream sites where HWMs were measured are listed in table 6 and follow the North Fork Maquoketa River profile.

\section{Summary}

Severe flooding occurred on June 4-5, 2002, in the Maquoketa River Basin in Delaware, Dubuque, Jackson, and Jones Counties following intense thunderstorms over eastcentral Iowa. Fourteen-hour rainfall recorded at Cascade at noon on June 4 was 6.0 inches. Radar indications estimated as much as 8 to 10 inches of rain fell in the upper-middle part of the Maquoketa River Basin. Peak discharges on the Maquoketa River at Monticello of 47,500 $\mathrm{ft}^{3} / \mathrm{s}$ (recurrence interval estimated to be greater than 500 years as computed using floodestimation equations developed by the USGS), and at the Maquoketa River near Maquoketa gaging station of 47,900 $\mathrm{ft}^{3} / \mathrm{s}$ (recurrence interval about 50 years), were determined for the flood. The peak discharge of the 2002 flood is nearly equal that of the 1944 flood $\left(48,000 \mathrm{ft}^{3} / \mathrm{s}\right)$, the largest flood on record in the Maquoketa River Basin. The 2002 flood is the largest known flood in the North Fork Maquoketa River Basin. A peak discharge of $22,600 \mathrm{ft}^{3} / \mathrm{s}$ (recurrence interval about 110 years) was determined for the flood at the North Fork Maquoketa River near Fulton gaging station.

\section{References}

Eash, D.A., 2001, Techniques for estimating flood-frequency discharges for streams in Iowa: U.S. Geological Survey Water-Resources Investigations Report 00-4233, 88 p.

Eash, D.A., 2004, Flood of June 4, 2002, in the Indian Creek Basin, Linn County, Iowa: U.S. Geological Survey OpenFile Report 2004-1074, 31 p. [Available online at URL http://pubs.water.usgs.gov/ofr2004-1074]

Gersema, Emily, 2002, June 6, Cedar Rapids Gazette, Associated Press, newspaper article.

Huff, F.A., and Angel, J.R., 1992, Rainfall frequency atlas of the Midwest: Champaign, IL, Illinois State Water Survey, Bulletin 71, 141 p. 


\section{Flood of June 4-5, 2002, in the Maquoketa River Basin, East-Central, lowa}

Interagency Advisory Committee on Water Data, 1982, Guidelines for determining flood flow frequency: Hydrology Subcommittee Bulletin 17B, 28 p. and appendixes.

Iowa Conservation Commission, 1979, Iowa's low-head dams - Their past, present, and future roles: Des Moines, Iowa, Iowa State Water Resources Research Institute Special Report no. 96, 312 p.

Iowa Department of Agriculture and Land Stewardship, State Climatologist Office, 2002, Iowa climate review: Johnston, Iowa, monthly summaries, v. 16, no. 6, 21 p.

Iowa Natural Resources Council, 1958, An inventory of water resources and water problems, northeastern Iowa river basins: Des Moines, Iowa, Iowa Natural Resources Council Bulletin no. 7, 74 p.

Larimer, O.J., 1957, Drainage areas of Iowa streams: Iowa Highway Research Board Bulletin No. 7 (reprinted 1974), 439 p.

Love, Orlan, 2002, June 7, Cedar Rapids Gazette newspaper article.

Love, Orlan, 2002, June 8, Cedar Rapids Gazette newspaper article.

Love, Orlan, 2002, June 11, Cedar Rapids Gazette newspaper article.

Love, Orlan, 2002, June 19, Cedar Rapids Gazette newspaper article.

Love, Orlan, 2002, July 13, Cedar Rapids Gazette newspaper article.
Love, Orlan, 2004, March 1, Cedar Rapids Gazette newspaper article.

Love, Orlan, and Lucas, Marlene, 2002, June 5, Cedar Rapids Gazette newspaper article.

Owens, Kristophere, 2002, June 5, Cedar Rapids Gazette newspaper article.

Pitt, David, 2002, June 5, Waterloo-Cedar Falls Courier, Associated Press, newspaper article.

Prior, J.C., 1991, Landforms of Iowa: Iowa City, Iowa Department of Natural Resources, University of Iowa Press, $153 \mathrm{p}$

U.S. Department of Commerce, National Oceanic and Atmospheric Administration, and National Climatic Data Center, 2002a, Climatological data, Iowa, June 2002: Asheville, N.C., monthly summaries, v. 113, no. 6, p. 48.

U.S. Department of Commerce, National Oceanic and Atmospheric Administration, and National Climatic Data Center, 2002b, Hourly precipitation data, Iowa, June 2002:

Asheville, N.C., monthly summaries, v. 52, no. 6, p. 20.

U.S. Department of Commerce, National Oceanic and Atmospheric Administration, and National Weather Service, 2002, Monthly report of rivers and flood conditions, Davenport, Iowa, Hydrologic Service Area, June 2002: National Weather Service, WS Form E-5, 3 p.

U.S. Department of Commerce, Weather Bureau, and Iowa Department of Agriculture, 1944, Climatological data, Iowa: Des Moines, Iowa, monthly summaries, v. 55, no. 6, p. 57-84. 


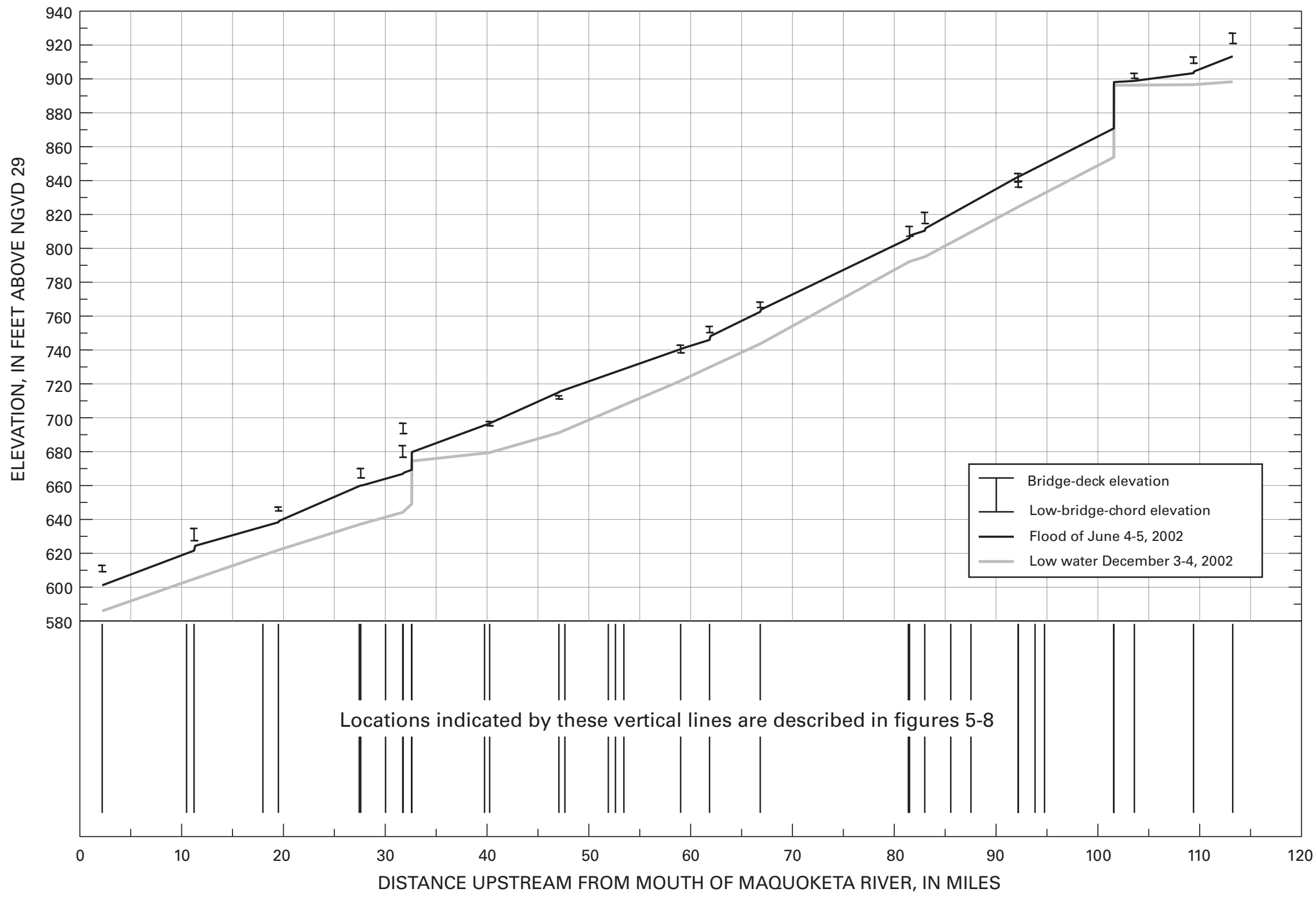

Figure 4. Profile of the June 2002 flood for the Maquoketa River, lowa; river miles 0 to 113. 


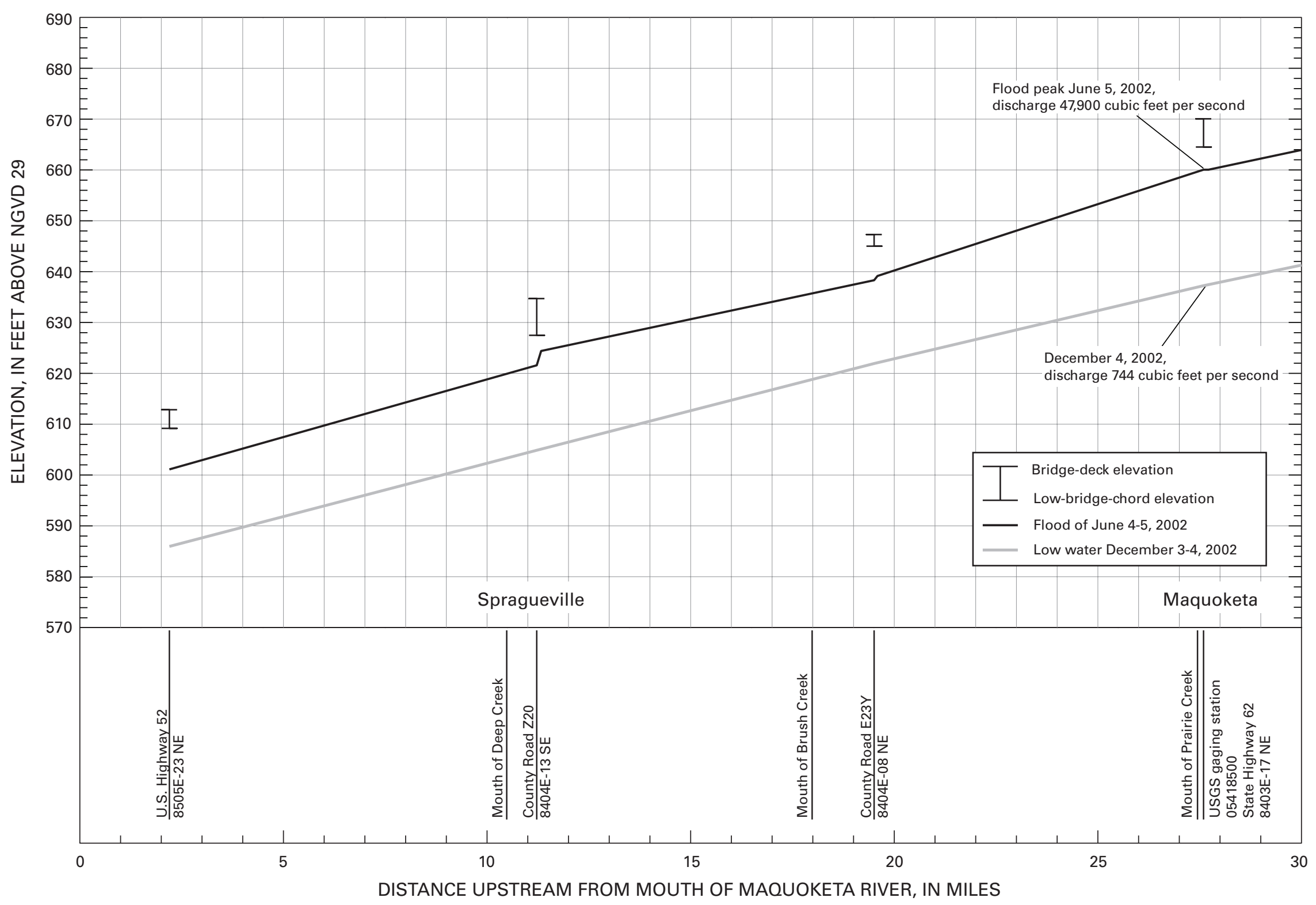

Figure 5. Profile of the June 2002 flood for the Maquoketa River, lowa; river miles 0 to 30. 


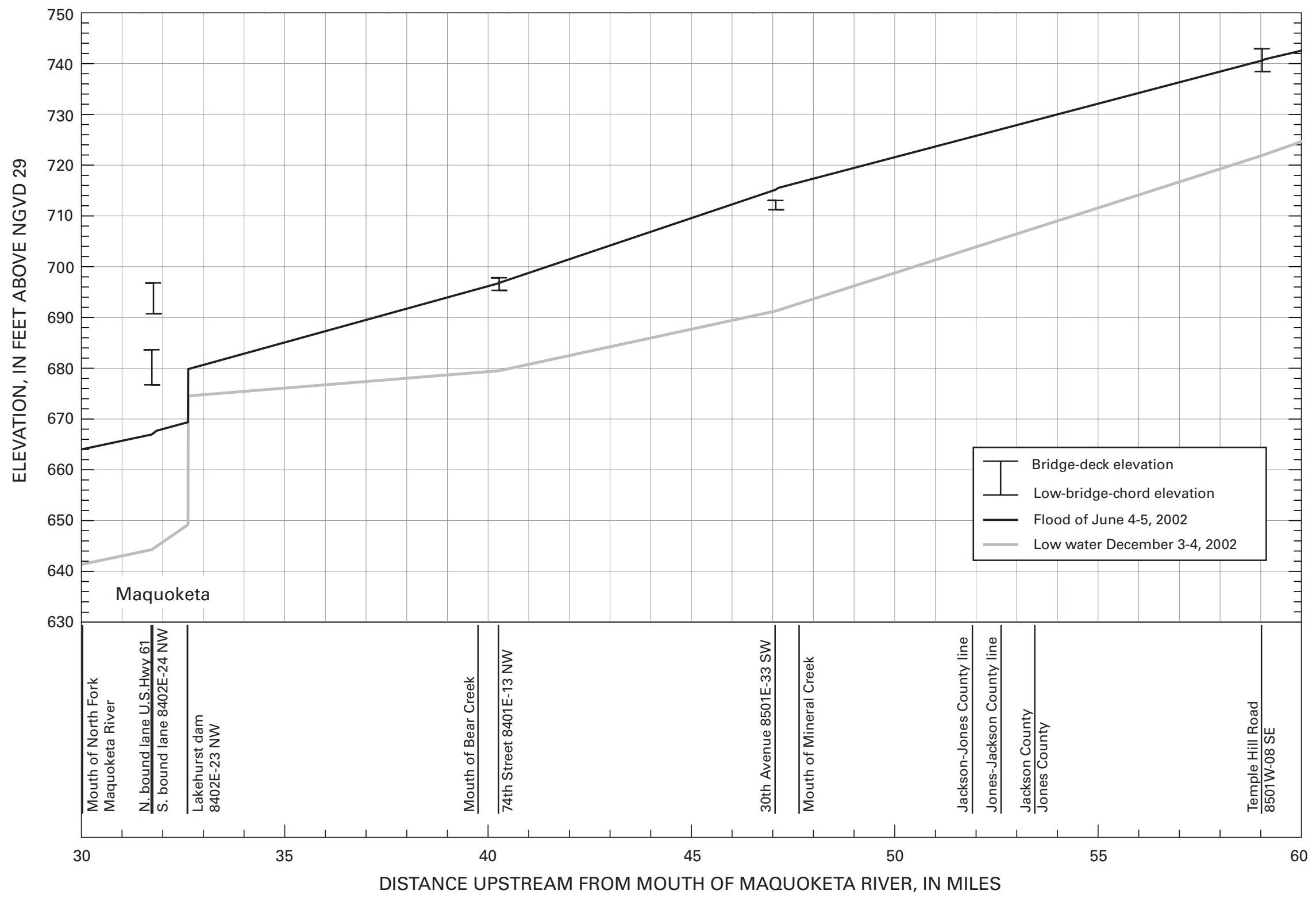

DISTANCE UPSTREAM FROM MOUTH OF MAQUOKETA RIVER, IN MILES 


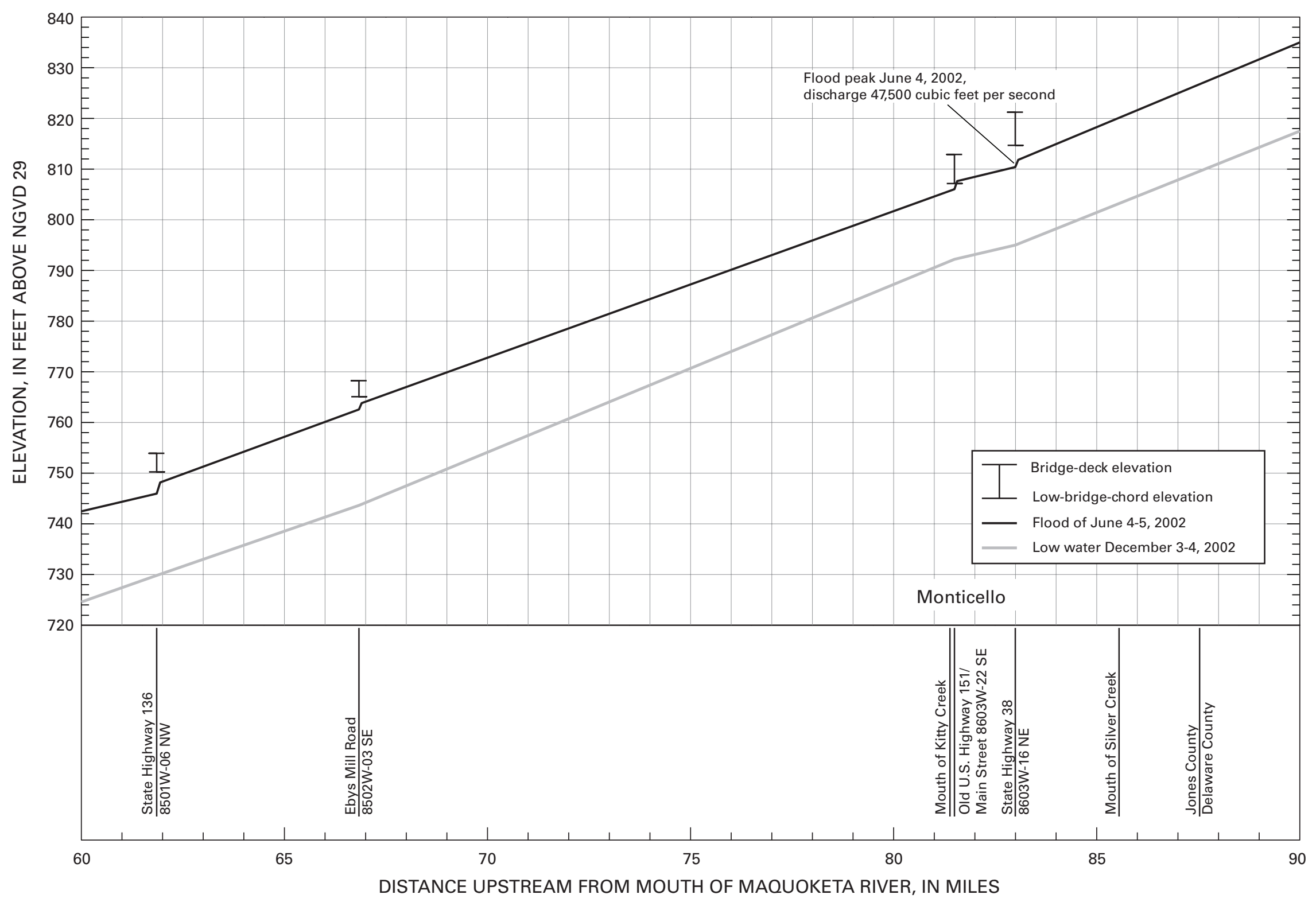

Figure 7. Profile of the June 2002 flood for the Maquoketa River, lowa; river miles 60 to 90. 


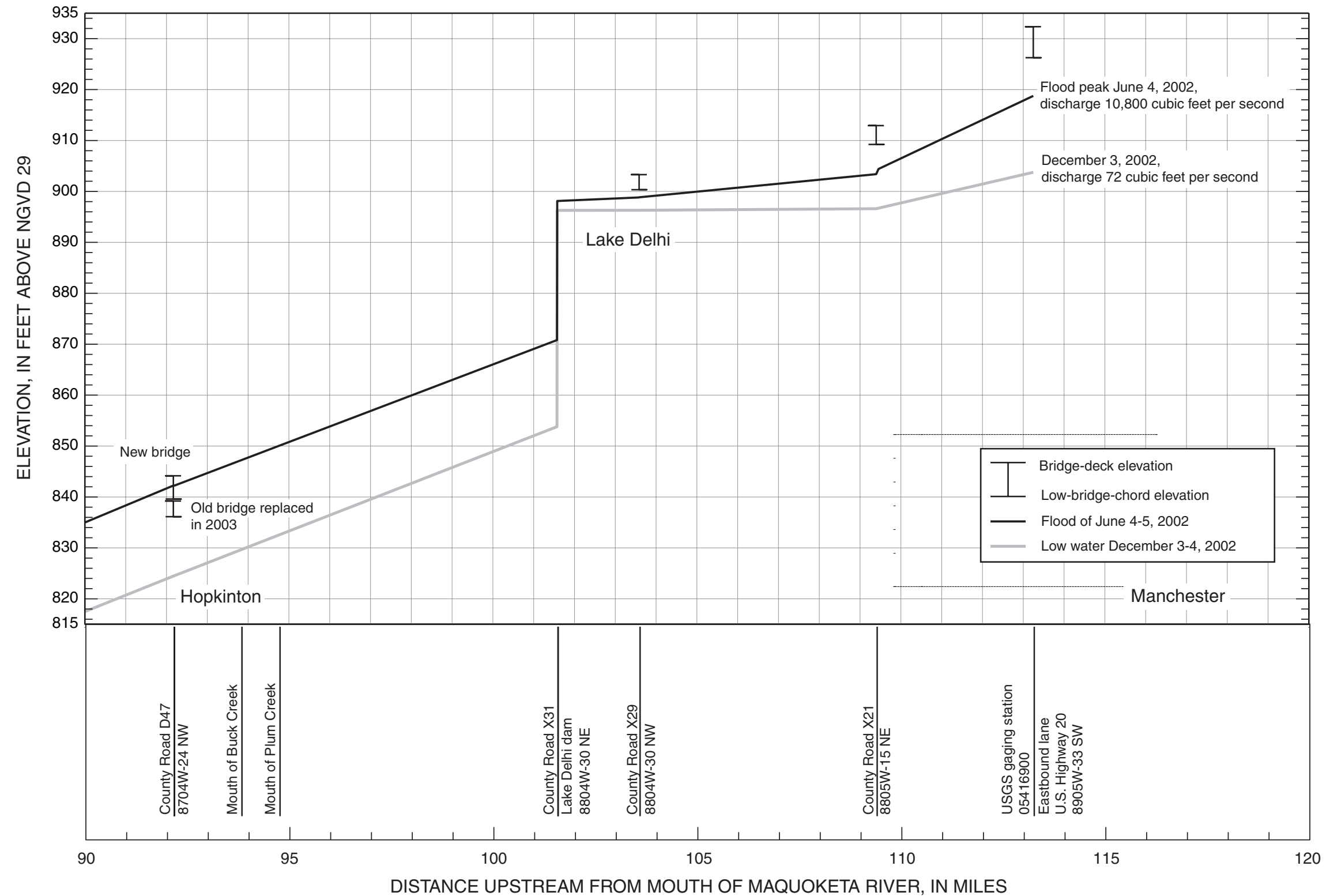




\section{Flood of June 4-5, 2002, in the Maquoketa River Basin, East-Central, lowa}

Table 5. Elevations of high-water marks used in the June 2002 flood profile for the Maquoketa River, lowa.

[HWM, high-water mark; NGVD 29, elevation data are referenced to the National Geodetic Vertical Datum of 1929; --, not determined]

\begin{tabular}{|c|c|c|c|}
\hline $\begin{array}{c}\text { Distance } \\
\text { upstream from } \\
\text { mouth of } \\
\text { Maquoketa River } \\
\text { (river miles) }\end{array}$ & Site description & $\begin{array}{c}\text { Downstream } \\
\text { HWM } \\
\text { (feet above } \\
\text { NGVD 29) }\end{array}$ & $\begin{array}{l}\text { Upstream } \\
\text { HWM } \\
\text { (feet above } \\
\text { NGVD 29) }\end{array}$ \\
\hline 2.20 & U.S. Highway 52, NW of Green Island & 601.11 & -- \\
\hline 11.22 & County Road Z20/387th Avenue, N of Spragueville & 621.58 & 624.40 \\
\hline 19.51 & County Road E23Y/Iron Bridge Road, SE of Andrew & 638.31 & 639.15 \\
\hline 27.60 & $\begin{array}{l}\text { USGS gaging station 05418500, State Highway 62, NE of } \\
\text { Maquoketa }\end{array}$ & 660.05 & 660.05 \\
\hline 31.72 & U.S. Highway 61, Maquoketa & 666.85 & 667.58 \\
\hline 32.61 & Lakehurst Dam, W of Maquoketa & ${ }^{1} 669.27$ & 679.72 \\
\hline 40.26 & 74th Street, NE of Baldwin & 696.66 & 696.79 \\
\hline 47.06 & 30th Avenue, N of Monmouth & 715.06 & 715.41 \\
\hline 59.02 & Temple Hill Road, NW of Canton & 740.50 & 740.76 \\
\hline 61.86 & State Highway 136, NE of Scotch Grove & 745.96 & 748.17 \\
\hline 66.84 & Ebys Mill Road, NE of Scotch Grove & 762.57 & 763.82 \\
\hline 81.50 & Old U.S. Highway 151/Main Street, Monticello & 806.03 & 807.63 \\
\hline 83.00 & State Highway 38, Monticello & 810.40 & 811.82 \\
\hline 92.17 & County Road D47/Marion Street, SW of Hopkinton & 842.24 & 842.24 \\
\hline 101.58 & $\begin{array}{l}\text { County Road X31/230th Avenue crossing Lake Delhi dam, SW of } \\
\text { Delhi }\end{array}$ & 870.81 & 898.12 \\
\hline 103.58 & County Road X29/220th Avenue, SW of Delhi & 898.82 & 898.85 \\
\hline 109.40 & County Road X21/240th Street, SE of Manchester & 903.39 & 904.41 \\
\hline 113.25 & $\begin{array}{l}\text { USGS gaging station } 05416900 \text {, eastbound lane of U.S. Highway } \\
\text { 20,S of Manchester }\end{array}$ & 918.76 & -- \\
\hline
\end{tabular}

\footnotetext{
${ }^{1}$ High-water mark provided by Iowa Department of Natural Resources.
} 


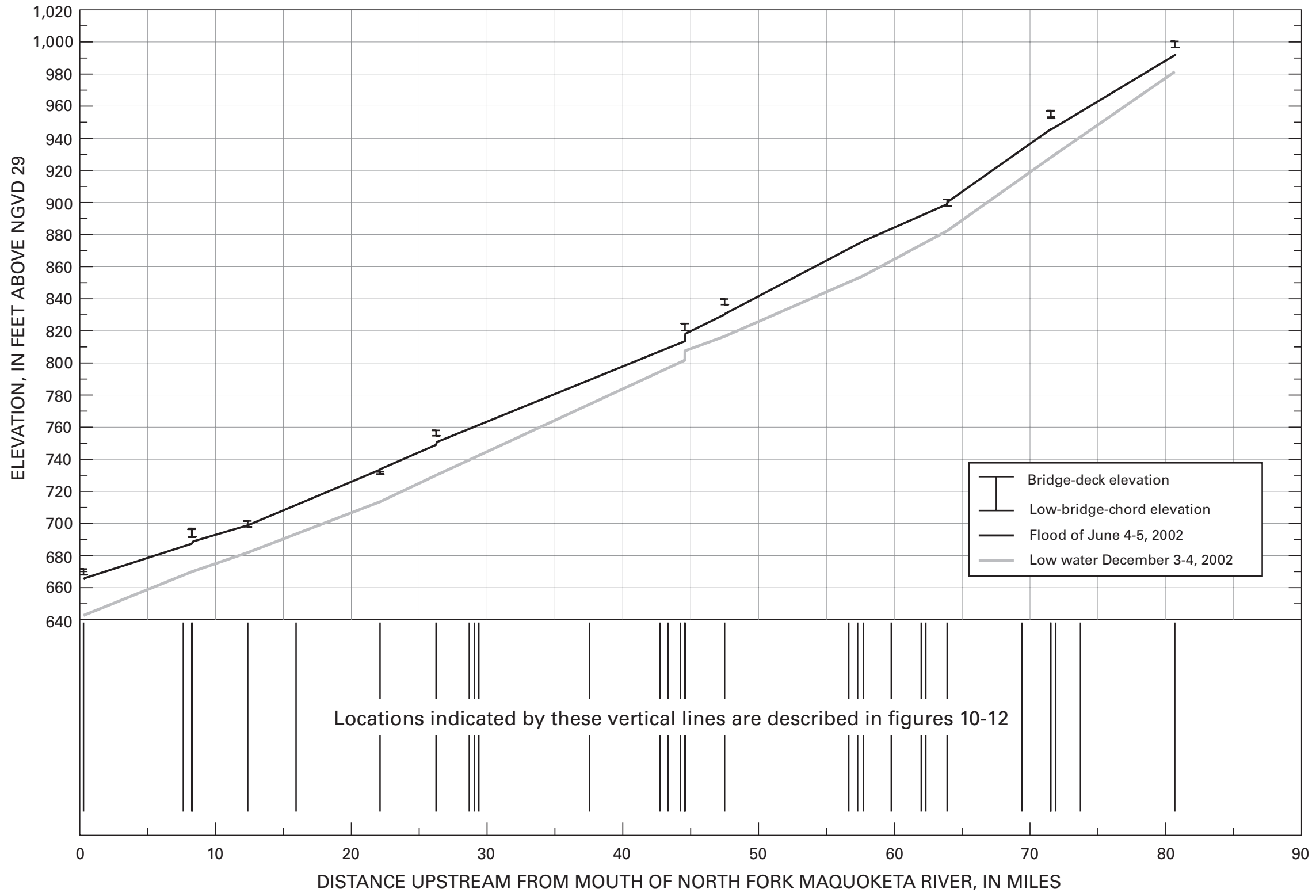

DISTANCE UPSTREAM FROM MOUTH OF NORTH FORK MAOUOKETA RIVER, IN MILES 


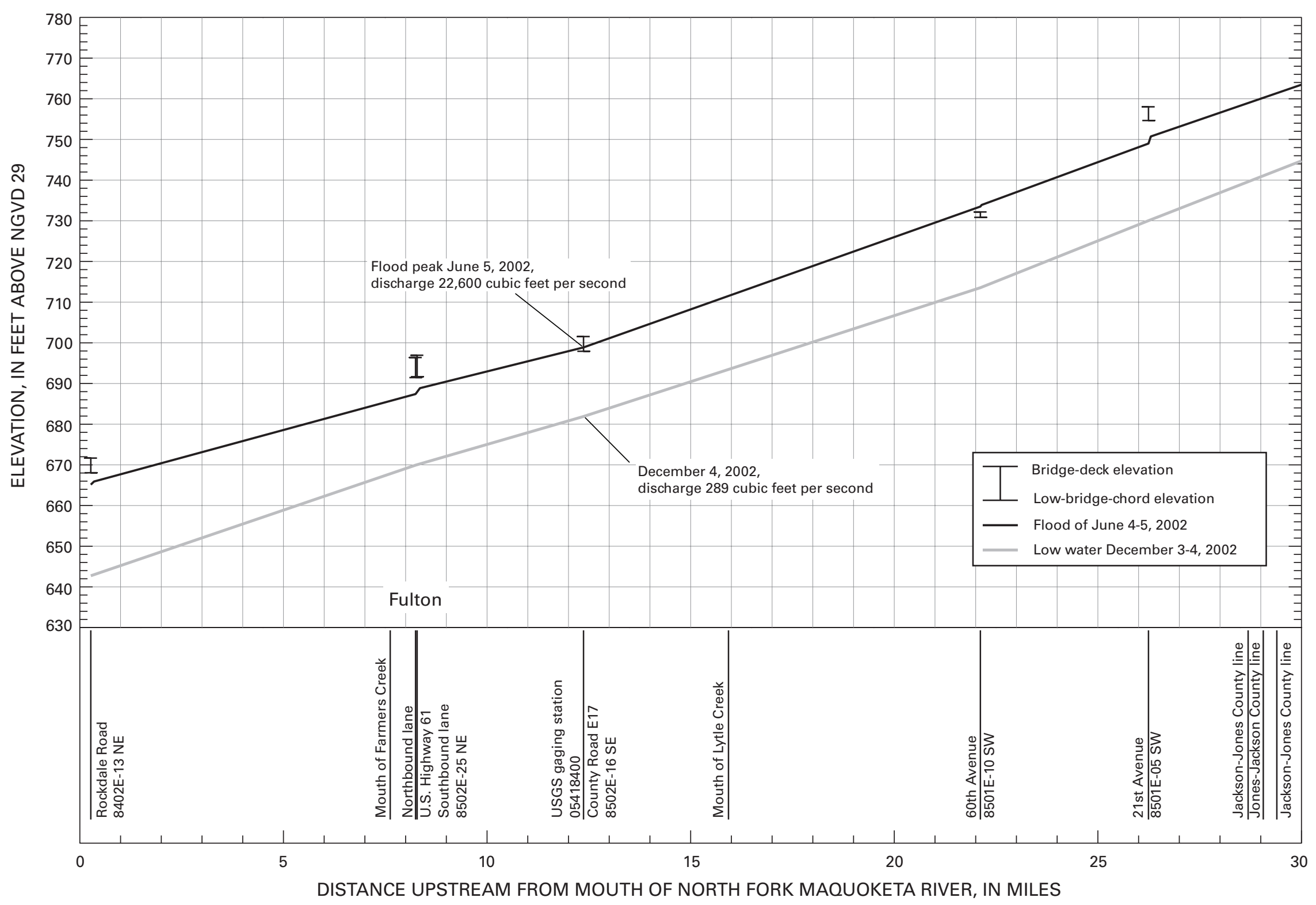

Figure 10. Profile of the June 2002 flood for the North Fork Maquoketa River, lowa; river miles 0 to 30. 


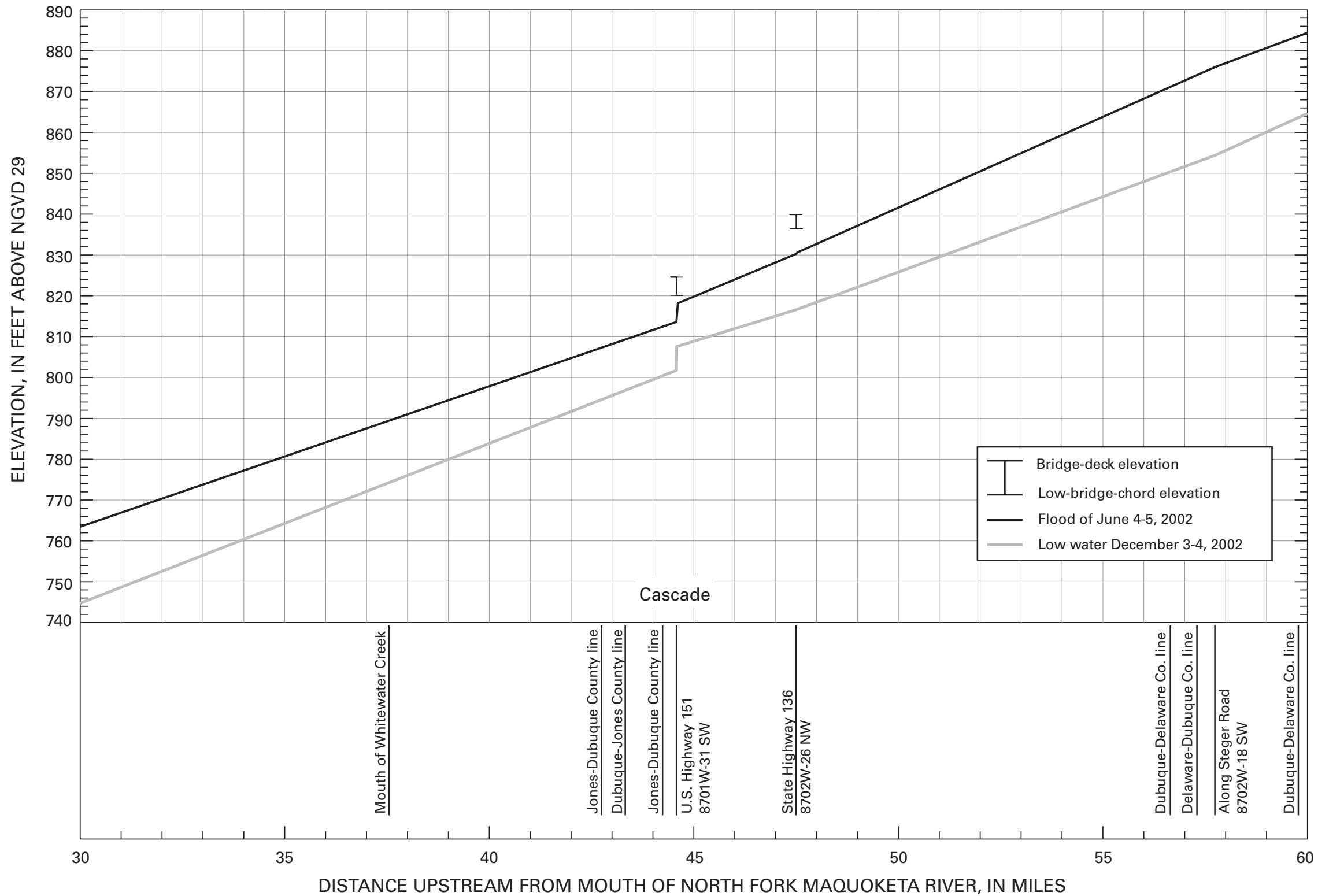

Figure 11. Profile of the June 2002 flood for the North Fork Maquoketa River, lowa; river miles 30 to 60. 


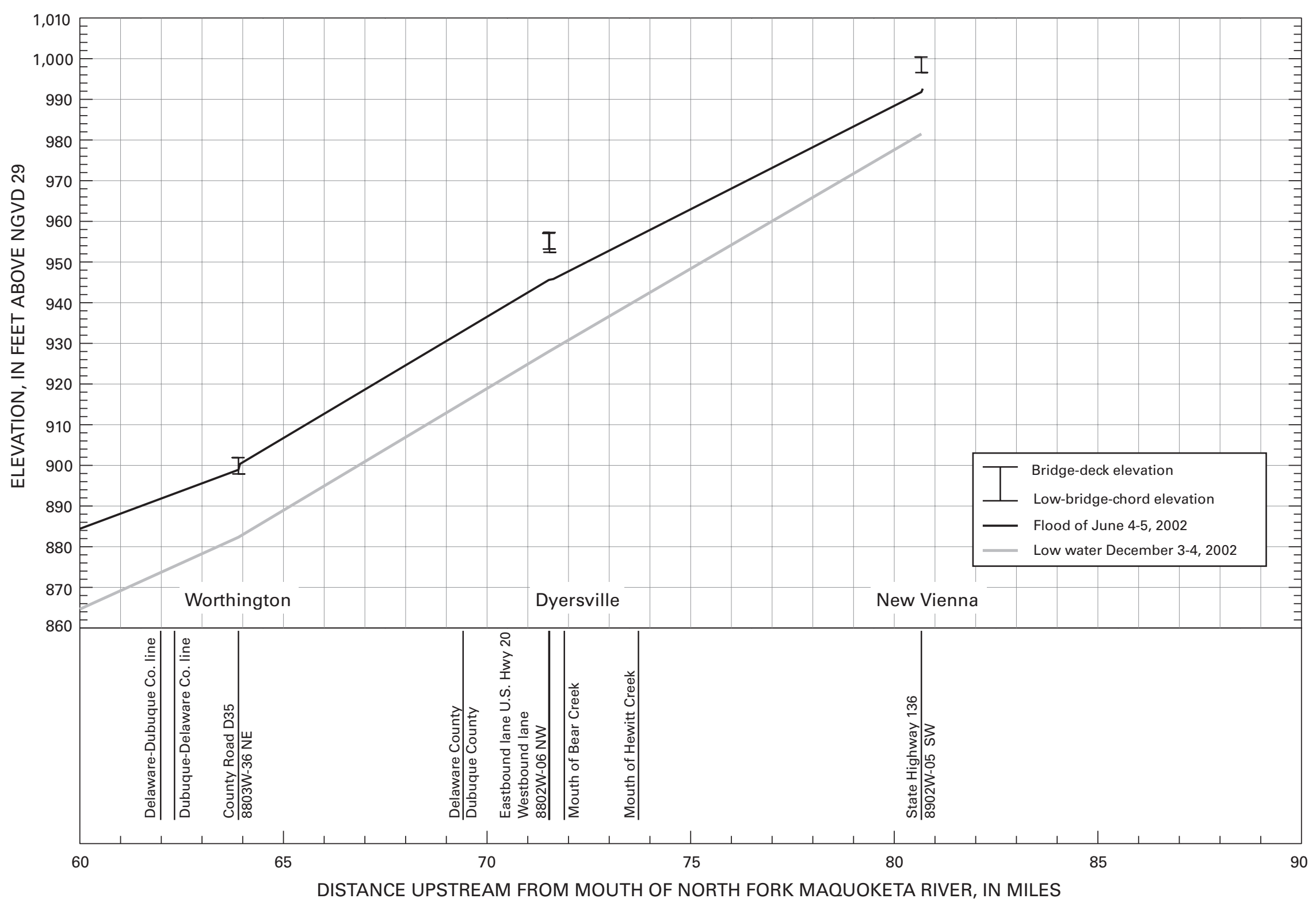

Figure 12. Profile of the June 2002 flood for the North Fork Maquoketa River, lowa; river miles 60 to 81 . 
Table 6. Elevations of high-water marks used in the June 2002 flood profile for the North Fork Maquoketa River, lowa.

[HWM, high-water mark; NGVD 29, elevation data are referenced to the National Geodetic Vertical Datum of 1929; --, not determined]

\begin{tabular}{|c|c|c|c|}
\hline $\begin{array}{c}\text { Distance } \\
\text { upstream from } \\
\text { mouth of North } \\
\text { Fork Maquoketa } \\
\text { River } \\
\text { (river miles) }\end{array}$ & Site description & $\begin{array}{c}\text { Downstream } \\
\text { HWM } \\
\text { (feet above } \\
\text { NGVD 29) }\end{array}$ & $\begin{array}{c}\text { Upstream } \\
\text { HWM } \\
\text { (feet above } \\
\text { NGVD 29) }\end{array}$ \\
\hline 0.27 & Rockdale Road, N of Maquoketa & 665.13 & 665.90 \\
\hline 8.24 & $\begin{array}{l}\text { Discontinued USGS gaging station 05418450, U.S. Highway } 61 \text {, } \\
\text { S of Fulton }\end{array}$ & 687.40 & 688.85 \\
\hline 12.37 & $\begin{array}{l}\text { USGS gaging station } 05418400 \text {, County Road E17/150th Street, } \\
\text { NW of Fulton }\end{array}$ & 698.87 & -- \\
\hline 22.12 & 60th Avenue, NE of Canton & 733.50 & 733.89 \\
\hline 26.24 & 21st Avenue, NE of Canton & 748.99 & 750.73 \\
\hline 44.58 & Old U.S. Highway 151/1st Avenue West, Cascade & 813.60 & 818.18 \\
\hline 47.50 & State Highway 136, NW of Cascade & 830.25 & 830.65 \\
\hline 57.74 & Along Steger Road, S of Worthington & 875.98 & -- \\
\hline 63.90 & County Road D35/272nd Street, W of Worthington & 898.91 & 900.34 \\
\hline 71.52 & U.S. Highway 20, Dyersville & 945.59 & 945.82 \\
\hline 80.67 & State Highway 136/Columbus Street, New Vienna & 991.79 & 992.62 \\
\hline
\end{tabular}





\section{Appendix: Temporary Bench Marks and Reference Points}

To facilitate measuring and referencing the high-water marks (HWMs) used in the flood profiles to a common datum, temporary bench marks (TBMs) and reference points (RPs) were found or established by the USGS at the bridges along the profiled river reaches. All TBM and RP elevations listed in this tabulation are referenced to the National Geodetic Vertical Datum of 1929. Tables 5 and 6 list the 29 sites where the USGS measured HWMs for the June 2002 flood profile. Of these 29 sites, TBMs are presented in this appendix for 28 of the sites and RPs are presented for 22 of the sites. For 6 of the 28 sites listed in this appendix, TBMs and corresponding elevations were established by other agencies and these agencies are noted in the descriptions of the TBMs. The USGS established TBMs at 22 sites and RPs at 22 sites during 2002, with the exception of TBMs or reference marks (RMs) established at three USGS streamflow-gaging stations prior to 2002, which are identified in this tabulation with an RM number. TBM and RP elevations established by the USGS were determined from differential leveling, with the exception of TBMs at 17 bridges, where elevations were determined from post-processed differential positioning using a global positioning system (GPS). Elevations determined using GPS are noted in the TBM and RP descriptions. Level lines or GPS networks, used to establish the thirdorder accuracy of the 22 TBMs established by the USGS shown herein, were surveyed or configured from bench marks established and adjusted by the National Mapping Division of the USGS and National Geodetic Survey. Errors of closure in the USGS level work were adjusted along level lines to balance TBM and RP elevations. Specific GPS-network and satelliteconstellation configurations, equivalent hours of data collection with multiple GPS receivers, and post-processing quality controls were used to control the effects of error in GPS-derived elevations. For the new County Road D47/Marion Street bridge over the Maquoketa River southwest of Hopkinton, the USGS established the elevation of the TBM by surveying from a spike in a utility pole located about $1,000 \mathrm{ft}$ southwest of the bridge for which the elevation was provided by the Delaware County Engineer's Office.

The TBMs and RPs are designated by an index number or legal description derived from their respective locations using Public Land Survey System coordinates (township, range, section). Within the section, the quarter section in which the TBM or RP is located is designated by NE, SE, NW, and SW. For example, 8505E-23 NE refers to a location in Township 85 North, Range 5 East, northeast quarter of section 23. A number in parentheses following the quarter-section designation indicates the number of the TBM or RP in that particular quarter section. The index number serves to describe the legal description of the mark without further reference in the body of the description. The physical location of the TBM on a bridge dictates the appropriate legal description. An RP, and any additional TBMs, are listed with the related TBM and are identified by the same legal description though, at times, they are in a different section, range, or township as determined by upstream or downstream location.

Standard marks, such as squares, crosses, or marks were chiseled or filed on concrete or metal; or existing bolts on bridges were used as TBMs or RPs. RPs are distinguished from TBMs by the notation "(REFERENCE POINT)" following the legal description. RPs were established to permit water-surface elevations to be determined by use of a tape and weight. The terms "right" and "left" in the descriptions are determined as viewed while facing in the downstream direction.

The TBMs and RPs are listed in the downstream to upstream order with respect to their correspondence to bridges over the Maquoketa and North Fork Maquoketa Rivers. The user of this information is cautioned that TBMs and RPs listed herein might have been disturbed, destroyed, or moved since elevations were established. It is the responsibility of the user to determine the condition and the suitability of the TBM or RP.

\section{Maquoketa River}

8505E-23 NE (1) --Approximately 1 mi northwest of Green Island, on U.S. Highway 52 bridge over Maquoketa River, on right downstream wingwall; Iowa Department of Transportation bench mark. Elevation determined using GPS.

Elevation $615.70 \mathrm{ft}$

8505E-23 NE (2) --Approximately 1 mi northwest of Green Island, on U.S. Highway 52 bridge over Maquoketa River, on left upstream wingwall; Iowa Department of Transportation bench mark. Elevation determined using GPS.

\section{Elevation $615.69 \mathrm{ft}$}

8505E-23 NE (3) --Approximately 1 mi northwest of Green Island, on U.S. Highway 52 bridge over Maquoketa River, on concrete platform at curb level at left upstream end of bridge; Iowa Department of Transportation bench mark. Elevation determined using GPS.

\section{Elevation $613.57 \mathrm{ft}$}

8505E-23 NE (4) --(REFERENCE POINT) Approximately 1 mi northwest of Green Island, on U.S. Highway 52 bridge over Maquoketa River, on concrete platform behind 7th drain from left downstream end of bridge; chiseled square. Elevation determined using GPS.

Elevation $614.29 \mathrm{ft}$ 
8404E-13 SE (1)--Approximately 0.75 mi north of Spragueville, on County Road Z20/387th Avenue bridge over Maquoketa River, on outer wingwall about $1.5 \mathrm{ft}$ from guardrail at left downstream end of bridge; chiseled square. Elevation determined using GPS.

\section{Elevation $635.01 \mathrm{ft}$}

8404E-13 SE (2)--(REFERENCE POINT) Approximately 0.75 mi north of Spragueville, on County Road Z20/387th Avenue bridge over Maquoketa River, behind 18th guardrail post from right downstream end of bridge; three filed marks. Elevation determined using GPS.

\section{Elevation $638.93 \mathrm{ft}$}

8404E-08 NE (1)--Approximately $5 \mathrm{mi}$ southeast of Andrew, on County Road E23Y/Iron Bridge Road over Maquoketa River, on corner of lower wingwall at left upstream end of bridge; chiseled square. Elevation determined using GPS.

\section{Elevation $647.40 \mathrm{ft}$}

8404E-08 NE (2)--(REFERENCE POINT) Approximately 5 mi southeast of Andrew, on County Road E23Y/Iron Bridge Road over Maquoketa River, on guardrail about $8 \mathrm{ft}$ left of $2 \mathrm{nd}$ vertical truss member from right downstream end of bridge; three filed marks. Elevation determined using GPS.

Elevation $661.14 \mathrm{ft}$

8403E-17 NE (1)--Approximately 1.5 mi northeast of Maquoketa, on State Highway 62 bridge over Maquoketa River, on top of right downstream abutment; chiseled square. (RM 19)

\section{Elevation 670.77 ft}

8403E-17 NE (2)--Approximately 1.5 mi northeast of Maquoketa, on State Highway 62 bridge over Maquoketa River, on top of right upstream abutment; chiseled square. (RM 20)

\section{Elevation $670.78 \mathrm{ft}$}

8402E-24 NW (1)--At Maquoketa, on northbound lane of U.S. Highway 61 bridge over Maquoketa River (downstream bridge), on right upstream wingwall; Iowa Department of Transportation bench mark. Elevation provided by Iowa Department of Transportation.

\section{Elevation $683.94 \mathrm{ft}$}

8402E-24 NW (2)--At Maquoketa, on southbound lane of U.S. Highway 61 bridge over Maquoketa River (upstream bridge), on right downstream wingwall; Iowa Department of Transportation bench mark.

\section{Elevation $699.76 \mathrm{ft}$}

8402E-24 NW (3)--(REFERENCE POINT) At Maquoketa, on northbound lane of U.S. Highway 61 bridge over Maquoketa River (downstream bridge), on concrete platform behind 7th drain from either end of bridge; chiseled square.

\section{Elevation $683.08 \mathrm{ft}$}

8401E-13 NW (1)--Approximately $2.5 \mathrm{mi}$ northeast of Baldwin, on 74th Street bridge over Maquoketa River, top of bolt at end of wood beam near last guardrail post at left downstream end of bridge; filed cross. Elevation determined using GPS.

Elevation $698.74 \mathrm{ft}$

8401E-13 NW (2)--(REFERENCE POINT) Approximately 2.5 mi northeast of Baldwin, on 74th Street bridge over Maquoketa River, on guardrail about $1 \mathrm{ft}$ left of guardrail post between 2 nd and 3rd vertical truss members from left downstream end of bridge; three filed marks. Elevation determined using GPS.

Elevation $701.33 \mathrm{ft}$

8501E-33 SW (1)--Approximately $3.5 \mathrm{mi}$ north of Monmouth, on 30th Avenue bridge over Maquoketa River, top of threaded bolt on outer downstream side of left downstream pier; filed cross. Elevation determined using GPS.

Elevation $713.56 \mathrm{ft}$

8501E-33 SW (2)--(REFERENCE POINT) Approximately $3.5 \mathrm{mi}$ north of Monmouth, on 30th Avenue bridge over Maquoketa River, on guardrail about $0.5 \mathrm{ft}$ left of guardrail post between 2nd and 3rd vertical truss members from left downstream end of bridge; three filed marks. Elevation determined using GPS.

Elevation $719.18 \mathrm{ft}$

8501W-08 SE (1)--Approximately 4.25 mi northwest of Canton, on Temple Hill Road bridge over Maquoketa River, on right downstream wingwall; chiseled cross. Elevation determined using GPS.

Elevation $749.79 \mathrm{ft}$

8501W-08 SE (2)--(REFERENCE POINT) Approximately 4.25 mi northwest of Canton, on Temple Hill Road bridge over Maquoketa River, on concrete barrier wall at 20th concrete post from left downstream end of bridge; chiseled square. Elevation determined using GPS.

Elevation $746.61 \mathrm{ft}$

8501W-06 NW (1)--Approximately 5.75 mi northeast of Scotch Grove, on State Highway 136 bridge over Maquoketa River, on left upstream wingwall; Iowa Department of Transportation bench mark. Elevation determined using GPS.

Elevation $756.74 \mathrm{ft}$

8501W-06 NW (2)--(REFERENCE POINT) Approximately 5.75 mi northeast of Scotch Grove, on State Highway 136 bridge over Maquoketa River, on concrete platform behind 4th drain from left downstream end of bridge; chiseled square. Elevation determined using GPS.

Elevation $757.03 \mathrm{ft}$ 
8502W-03 SE (1)--Approximately 3 mi northeast of Scotch Grove, on Ebys Mill Road bridge over Maquoketa River, on right downstream wingwall; chiseled cross. Elevation determined using GPS.

\section{Elevation $771.02 \mathrm{ft}$}

8502W-03 SE (2)--(REFERENCE POINT) Approximately 3 mi northeast of Scotch Grove, on Ebys Mill Road bridge over Maquoketa River, on 21st guardrail post from right downstream end of bridge; three filed marks. Elevation determined using GPS.

\section{Elevation $771.47 \mathrm{ft}$}

8603W-22 SE (1)--At Monticello, on old U.S. Highway 151/Main Street bridge over Maquoketa River, on outside curb behind guardwall at left upstream end of bridge; Iowa Department of Transportation bench mark.

\section{Elevation $813.68 \mathrm{ft}$}

8603W-22 SE (2)--(REFERENCE POINT) At Monticello, on old U.S. Highway 151/Main Street bridge over Maquoketa River, on concrete platform behind 7th drain from left downstream end of bridge; chiseled square.

\section{Elevation $814.16 \mathrm{ft}$}

8603W-16 NE (1)--At Monticello, on State Highway 38 bridge over Maquoketa River, on left upstream wingwall; Iowa Department of Transportation bench mark. Elevation provided by Iowa Department of Transportation.

\section{Elevation $823.96 \mathrm{ft}$}

8603W-16 NE (2)--(REFERENCE POINT) At Monticello, on State Highway 38 bridge over Maquoketa River, on concrete platform right of $21 \mathrm{st}$ metal bracket from right downstream end of bridge and across from center of 3rd and 4th drains from right upstream end of bridge; chiseled square.

\section{Elevation $824.68 \mathrm{ft}$}

8704W-24 NW (1)--Approximately $0.5 \mathrm{mi}$ southwest of Hopkinton, on County Road D47/Marion Street bridge over southern channel of Maquoketa River, on left downstream end of sidewalk concrete barrier wall; Delaware County bench mark. Elevation of bench mark on bridge surveyed by USGS from elevation southwest of bridge provided by Delaware County Engineer's Office.

\section{Elevation $846.90 \mathrm{ft}$}

8804W-30 NE (1)--Approximately $1.5 \mathrm{mi}$ southwest of Delhi, on County Road X31/230th Avenue crossing Lake Delhi dam on Maquoketa River, on end of right downstream wingwall; chiseled cross. Elevation determined using GPS.

Elevation $907.37 \mathrm{ft}$

8804W-30 NW (1)--Approximately 2 mi southwest of Delhi, on County Road X29/220th Avenue bridge over Lake Delhi, on corner of wingwall near guardrail at left downstream end of bridge; chiseled square. Elevation determined using GPS.
8804W-30 NW (2)--(REFERENCE POINT) Approximately 2 mi southwest of Delhi, on County Road X29/220th Avenue bridge over Lake Delhi, on metal guardrail between 11th and 12th guardrail posts from right downstream end of bridge; three filed marks. Elevation determined using GPS.

Elevation $911.45 \mathrm{ft}$

8805W-15 NE (1)--Approximately $4 \mathrm{mi}$ southeast of Manchester, on County Road X21/240th Street bridge over Maquoketa River, on corner of wingwall near guardrail at right upstream end of bridge; chiseled square. Elevation determined using GPS.

Elevation $915.58 \mathrm{ft}$

8805W-15 NE (2)--(REFERENCE POINT) Approximately 4 mi southeast of Manchester, on County Road X21/240th Street bridge over Maquoketa River, on metal guardrail behind 3rd drain from right downstream end of bridge; three filed marks. Elevation determined using GPS.

Elevation $917.32 \mathrm{ft}$

8905W-33 SW (1)--Approximately $0.5 \mathrm{mi}$ south of Manchester, on eastbound lane of U.S. Highway 20 bridge over Maquoketa River (downstream bridge), on left upstream abutment; Iowa Department of Transportation bench mark. (RM 1)

Elevation $938.14 \mathrm{ft}$

8905-33 SW (2)--Approximately $0.5 \mathrm{mi}$ south of Manchester, on eastbound lane of U.S. Highway 20 bridge over Maquoketa River (downstream bridge), on left downstream abutment; chiseled square. (RM 2)

Elevation $938.34 \mathrm{ft}$

\section{North Fork Maquoketa River}

8402E-13 NE (1)--Approximately 1 mi north of Maquoketa, on Rockdale Road bridge over North Fork Maquoketa River, on right downstream wingwall; Iowa Department of Transportation bench mark. Elevation determined using GPS.

Elevation $674.39 \mathrm{ft}$

8402E-13 NE (2)--(REFERENCE POINT) Approximately 1 mi north of Maquoketa, on Rockdale Road bridge over North Fork Maquoketa River, on guardrail about 3 inches right of 28th guardrail post from left downstream end of bridge; three filed marks. Elevation determined using GPS.

Elevation $675.24 \mathrm{ft}$

8502E-25 NE (1)--Approximately $0.5 \mathrm{mi}$ south of Fulton, on southbound lane of U.S. Highway 61 bridge over North Fork Maquoketa River (upstream bridge), on left downstream wingwall; Iowa Department of Transportation bench mark. Elevation supplied by Iowa Department of Transportation.

Elevation $699.52 \mathrm{ft}$ 
8502E-25 NE (2)--Approximately $0.5 \mathrm{mi}$ south of Fulton, on northbound lane of U.S. Highway 61 bridge over North Fork Maquoketa River (downstream bridge), on right downstream wingwall; Iowa Department of Transportation bench mark.

\section{Elevation $700.05 \mathrm{ft}$}

8502E-25 NE (3)--(REFERENCE POINT) Approximately $0.5 \mathrm{mi}$ south of Fulton, on northbound lane of U.S. Highway 61 bridge over North Fork Maquoketa River (downstream bridge), on concrete platform behind 4th drain from right downstream end of bridge; chiseled square.

\section{Elevation $697.68 \mathrm{ft}$}

8502E-16 SE (1)--Approximately 2.75 mi northwest of Fulton, on County Road E17/150th Street bridge over North Fork Maquoketa River, on left downstream wingwall; chiseled square. (RM 1)

\section{Elevation $711.21 \mathrm{ft}$}

8502E-16 SE (2)--Approximately $2.75 \mathrm{mi}$ northwest of Fulton, on County Road E17/150th Street bridge over North Fork Maquoketa River, on right upstream wingwall; chiseled square. (RM 3)

\section{Elevation $711.16 \mathrm{ft}$}

8501E-10 SW (1)--Approximately 3.25 mi northeast of Canton, on 60th Avenue bridge over North Fork Maquoketa River, top of right upstream bolt on right upstream pier; filed cross. Elevation determined using GPS.

\section{Elevation $732.21 \mathrm{ft}$}

8501E-10 SW (2)--(REFERENCE POINT) Approximately 3.25 mi northeast of Canton, on 60th Avenue bridge over North Fork Maquoketa River, on guardrail about $10 \mathrm{ft}$ left of 2nd vertical truss member from right downstream end of bridge; three filed marks. Elevation determined using GPS.

\section{Elevation $736.15 \mathrm{ft}$}

8501E-05 SW (1)--Approximately 2.5 mi northeast of Canton, on 21st Avenue bridge over North Fork Maquoketa River, on roadside end of concrete curb next to metal bracket at left downstream end of bridge; chiseled square. Elevation determined using GPS.

\section{Elevation $758.63 \mathrm{ft}$}

8501E-05 SW (2)--(REFERENCE POINT) Approximately $2.5 \mathrm{mi}$ northeast of Canton, on 21st Avenue bridge over North Fork Maquoketa River, on metal guardrail at 4th drain from right downstream end of bridge; three filed marks. Elevation determined using GPS.

\section{Elevation $767.33 \mathrm{ft}$}

8701W-31 SW (1)--At Cascade, on old U.S. Highway 151/1st Avenue West bridge over North Fork Maquoketa River, on corner of right downstream wingwall; Iowa Department of Transportation bench mark. Elevation provided by Iowa Department of Transportation.

Elevation $828.54 \mathrm{ft}$
8701W-31 SW (2)--(REFERENCE POINT) At Cascade, on old U.S. Highway 151/1st Avenue West bridge over North Fork Maquoketa River, on downstream side of cyclone fence centered between 8th and 9th fence posts from right downstream end of bridge; edge of concrete sidewalk.

Elevation $825.52 \mathrm{ft}$

8701W-31 SW (3)--(REFERENCE POINT) At Cascade, on old U.S. Highway 151/1st Avenue West bridge over North Fork Maquoketa River, on upstream side of cyclone fence centered between 8th and 9th fence posts from right upstream end of bridge; edge of concrete sidewalk.

Elevation $825.53 \mathrm{ft}$

8702W-26 NW (1)--Approximately 2 mi northwest of Cascade, on State Highway 136 bridge over North Fork Maquoketa River, on left downstream wingwall; Iowa Department of Transportation bench mark. Elevation determined using GPS.

Elevation $843.72 \mathrm{ft}$

8702W-26 NW (2)--Approximately 2 mi northwest of Cascade, on State Highway 136 bridge over North Fork Maquoketa River, on right downstream wingwall; Iowa Department of Transportation bench mark. Elevation determined using GPS.

Elevation $843.64 \mathrm{ft}$

8702W-26 NW (3)--(REFERENCE POINT) Approximately 2 mi northwest of Cascade, on State Highway 136 bridge over North Fork Maquoketa River, on concrete platform behind downstream concrete barrier wall across from 4th drain from either upstream end of bridge; chiseled square. Elevation determined using GPS.

Elevation $841.75 \mathrm{ft}$

8702W-18 SW (1)--Approximately $3.5 \mathrm{mi}$ south of Worthington, on Steger Road bridge over unnamed tributary to North Fork Maquoketa River, in post near right downstream wingwall of small wooden bridge; top of horizontal lagbolt head. Elevation determined using GPS.

Elevation $864.43 \mathrm{ft}$

8803W-36 NE (1)--Approximately $0.5 \mathrm{mi}$ west of Worthington, on County Road D35/272nd Street bridge over North Fork Maquoketa River, on left upstream wingwall; Delaware County bench mark. Elevation determined using GPS.

Elevation $904.62 \mathrm{ft}$

8803W-36 NE (2)--(REFERENCE POINT) Approximately $0.5 \mathrm{mi}$ west of Worthington, on County Road D35/272nd Street bridge over North Fork Maquoketa River, on concrete barrier wall between 13th and 14th concrete posts from left downstream end of bridge; chiseled square. Elevation determined using GPS.

Elevation $904.32 \mathrm{ft}$ 
8802W-06 NW (1)--At Dyersville, on eastbound lane of U.S. Highway 20 bridge over North Fork Maquoketa River (downstream bridge), on left upstream end of concrete barrier wall; Iowa Department of Transportation bench mark. Elevation provided by Iowa Department of Transportation.

Elevation $959.79 \mathrm{ft}$

8802W-06 NW (2)--At Dyersville, on eastbound lane of U.S. Highway 20 bridge over North Fork Maquoketa River (downstream bridge), on right upstream end of concrete barrier wall; chiseled cross. Elevation provided by Iowa Department of Transportation.

\section{Elevation $961.81 \mathrm{ft}$}

8802W-06 NW (3)--(REFERENCE POINT) At Dyersville, on eastbound lane of U.S. Highway 20 bridge over North Fork Maquoketa River (downstream bridge), on concrete barrier wall at 9 th drain from left downstream end of bridge; chiseled square.

Elevation $960.67 \mathrm{ft}$
8902W-05 SW (1)--At New Vienna, on State Highway 136/Columbus Street bridge over North Fork Maquoketa River, on left upstream end of concrete barrier wall; Iowa Department of Transportation bench mark. Elevation provided by Iowa Department of Transportation.

Elevation $1005.28 \mathrm{ft}$

8902W-05 SW (2)--At New Vienna, on State Highway 136/Columbus Street bridge over North Fork Maquoketa River, on right downstream end of concrete barrier wall; Iowa Department of Transportation bench mark.

\section{Elevation $1003.01 \mathrm{ft}$}

8902W-05 SW (3)--(REFERENCE POINT) At New Vienna, on State Highway 136/Columbus Street bridge over North Fork Maquoketa River, on concrete barrier wall between 2nd and 3rd drains from either downstream end of bridge; chiseled square.

Elevation $1004.25 \mathrm{ft}$ 
Prepared by the lowa District office: U.S. Geological Survey, WRD

Room 269, Federal Building

P.O. Box 1230

400 South Clinton Street

lowa City, IA 52244

Text layout by Ella M. Decker, USGS, Huron, South Dakota.

Graphics layout by Connie J. Ross, USGS, Huron, South Dakota.

This publication is available online at URL http://pubs.water.usgs.gov/ofr20041250

Information regarding the water resources in lowa is available at URL http://ia.water.usgs.gov/ 
